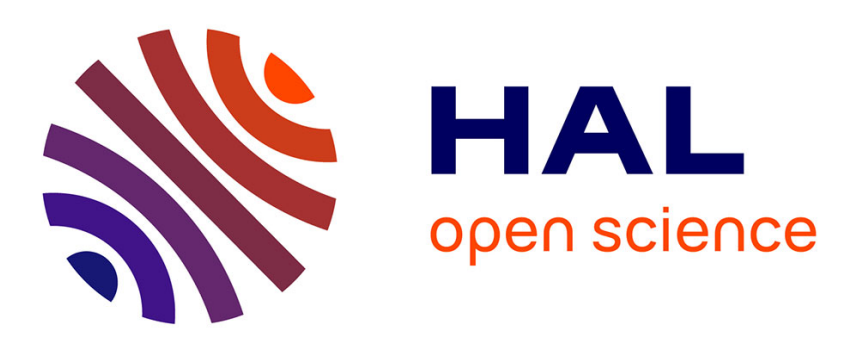

\title{
Effects of surfactant and nanofluid on the performance and optimization of a microchannel heat sink
}

Hielfarith Suffri Shamsuddin, Patrice Estellé, Javier Navas, Normah Mohd

Ghazali, Maziah Mohamad

\section{- To cite this version:}

Hielfarith Suffri Shamsuddin, Patrice Estellé, Javier Navas, Normah Mohd Ghazali, Maziah Mohamad. Effects of surfactant and nanofluid on the performance and optimization of a microchannel heat sink. International Journal of Heat and Mass Transfer, 2021, 175, pp.121336. 10.1016/j.ijheatmasstransfer.2021.121336 . hal-03225993

HAL Id: hal-03225993

https://hal-univ-rennes1.archives-ouvertes.fr/hal-03225993

Submitted on 13 May 2021

HAL is a multi-disciplinary open access archive for the deposit and dissemination of scientific research documents, whether they are published or not. The documents may come from teaching and research institutions in France or abroad, or from public or private research centers.
L'archive ouverte pluridisciplinaire HAL, est destinée au dépôt et à la diffusion de documents scientifiques de niveau recherche, publiés ou non, émanant des établissements d'enseignement et de recherche français ou étrangers, des laboratoires publics ou privés. 
Effects of surfactant and nanofluid on the performance and optimization of a microchannel heat sink

\title{
Hielfarith Suffri Shamsuddin ${ }^{a}$, Patrice Estellé ${ }^{\text {,** }}$, Javier Navas ${ }^{c}$, Normah Mohd Ghazali $^{\mathrm{a}, *}$, Maziah Mohamad ${ }^{\mathrm{a}}$
}

${ }^{a}$ School of Mechanical Engineering, Faculty of Engineering, Universiti Teknologi Malaysia

${ }^{\mathrm{b}}$ Univ Rennes, LGCGM, F-35000 Rennes, France

${ }^{\mathrm{c}}$ Departamento de Química Física, Facultad de Ciencias, Universidad de Cádiz, E-11510

Puerto Real (Cádiz), Spain

*Corresponding authors: patrice.estelle@univ-rennes1.fr ; normah@mail.fkm.utm.my

\begin{abstract}
:
This paper reports the influence of surfactant Triton X-100 on boron nitride nanotubes (BNNTs) nanofluid in non-optimized and optimized microchannel heat sink (MCHS) at $30^{\circ} \mathrm{C}$ and $50^{\circ} \mathrm{C}$. The MCHS performance was evaluated in terms of thermal resistance and pressure drop, utilizing experimental thermophysical properties of distilled water, a mixture of distilled water and surfactant Triton X-100 as base fluid, and nanofluid BNNTs at weight concentration of $0.001 \%$ into MCHS models which further optimized with the Multiple Objective Particle Swarm Optimization (MOPSO) technique. It is found that the surfactant at $30^{\circ} \mathrm{C}$ improves MCHS thermal capabilities without nanotubes by $0.8 \%$ even after optimizing MCHS according to the fluid properties. Conversely, surfactant Triton X-100 reduces pressure drop greatly with any change in thermal resistance at $50^{\circ} \mathrm{C}$ and paired cooperatively with BNNTs nanofluid $0.001 \mathrm{wt} . \%$ - mitigating pressure drop increment caused by the nanofluid resulting an overall performance improvement by $1.25 \%$ and $1.97 \%$ for thermal resistance and pressure drop respectively in MCHS systems and reduced to $1.3 \%$ and $3.2 \%$ after optimization. Optimized MCHS dimensions given by MOPSO could be manufactured and additionally gave wider solutions for large reduction of pressure drop up to $80 \%$ for economic MCHS with a drawback of higher thermal resistance.

Keywords: Microchannel, Heat Sink, Particle Swarm Optimization (PSO), Boron Nitride Nanotubes, Nanofluid, Surfactant effect
\end{abstract}

\section{Introduction}

Rapid advancement of technology has led to the miniaturization of the Integrated Circuits (IC) applicable in various digital applications and systems especially in Industry 4.0. This reduction in the size of circuits, however, has its limit especially in heating control which affects their durability and reliability. With the development of the micro-electro-mechanical system (MEMS) technology, Tuckerman and Pease (1981) have introduced a water-cooled microchannel heat sink (MCHS) with a $1 \mathrm{~cm}^{2}$ area capable to dissipate heat approximately 790 
$\mathrm{W} / \mathrm{cm}^{2}$ with a high toll of pressure drop up to $31 \mathrm{psi}$ which consequently requires a high power to operate. The temperature of the MCHS base or substrate increased up to $71^{\circ} \mathrm{C}$ above the fluid temperature while the usual temperature of IC is between $50^{\circ} \mathrm{C}$ to $100^{\circ} \mathrm{C}$ at that time. In their MCHS, a silicon material was attached on top of the IC unit as the base, with microchannels grooved as small as $50 \mu \mathrm{m}$ in width as well as in their wall thickness. Up to 100 microchannels were produced by an orientation-dependant etch of potassium hydroxide, $\mathrm{KOH}$.

Since future technology demands for a greater heat removal, numerous researches have been done to improve the capability of the MCHS. Base materials (Ijam \& Saidur, 2012; Peyghambarzadeh et al., 2014; Sarafraz et al., 2017; Yang et al., 2019; Yang et al., 2020), fluid flow alteration (Zhai et al., 2016a; Zhai et al., 2016b; Shen et al., 2018; Jiang et al., 2020) and mixing with inserts (Bahiraei et al., 2019), microchannel shape and layout (Ahmed et al., 2016; Wong \& Ang, 2017; Hemmat Esfe et al., 2017; Arani et al., 2017; Hajmohammadi \& Toghraei, 2018), complex design of microchannels walls (Chai et al., 2013; Sakanova et al., 2015; Ma et al., 2017; Duangthongsuk \& Wongwises, 2017; Shen et al., 2018; Sarlak et al., 2019), pin-fin hybrid (Alfellag et al., 2019; Soleymani et al., 2020; Zeng et al., 2020), implementation of manifolds (Pourfattah et al., 2019; Lin et al., 2021), jet injection (Jalali et al., 2019), double layers (Arani et al., 2017) and more have been consistently being explored to improve the performance of the MCHS. Additionally, Mohammed et al. (2010) stated that the conventional method using gas, air and water as coolant for a MCHS will no longer be able to address future heating issue to remove as minimum as $1000 \mathrm{~W} / \mathrm{cm}^{2}$.

Researches on "new" coolants have been widely developed and the utilization of nanofluid in a MCHS has emerged at the forefront, nanofluid being a combination of solid nanoparticles within a common base fluid such as water or ethylene glycol. Most common nanofluids consist of metallic nanoparticles such as copper (Mohammed et al., 2011; Sakanova et al., 2015; Azizi et al., 2016), titanium (Mohammed et al., 2011; Yu et al., 2016; Xia et al., 2016; Adham et al., 2016), silver (Mohammed et al., 2011; Sarafraz et al., 2018), and aluminium (Mohammed et al., 2011; Wang et al., 2013; Xia et al., 2016; Anbumeenakshi \& Thansekhar, 2017; Shi et al., 2018). However, researchers are still looking for alternatives since metals contribute towards a high friction factor. Thus, a nanofluid with non-metal and metalloid nanoparticles is attractive in MCHS. Some studies with carbon nanotubes (Halelfadl et al., 2014a; Sarafraz et al., 2017; Mohd-Ghazali et al., 2019), silicon (Mohammed et al., 2011; Sakanova et al., 2015), and even diamond (Sakanova et al., 2015) have been previously completed. In order to keep the nanofluid stable, Kamali et al. (2013) and Garg et al. (2015) who have performed experiments on a MCHS with carbon nanotubes concluded that a surfactant is necessary in nanofluid applications with MCHS as there is no other option to keep the nanofluid stable for a long duration as their MCHS experienced clogged channels due to nanoparticles agglomeration. Today, the presence of surfactants in nanofluids is generally required.

Although there are physical treatments to stabilize a nanofluid, a surfactant is still needed for a long period stability. Garg et al. (2015) highlighted that different surfactants, however, can change the nanofluid properties even slightly and this may consequently affect 
the performance of a nanofluid as a coolant. Many surfactants have already been tested with various nanoparticles such as Sodium Dodecylbenzene (SDBS) (Wusiman et al., 2013; Estellé et al., 2015; Kim et al., 2018), Sodium Dodecyl Sulphate (SDS) (Kim et al., 2018), Cetyl Trimenthyl Ammonium Bromide (CTAB) (Leong et al., 2016; Choi et al., 2018), Polyvinylpyrrolidone (PVP), and Gum Arabic (Leong et al., 2016). As reported by Askar et al. (2020) and Ma et al. (2021), different surfactants can both positively or negatively affect the thermophysical properties of a nanofluid and their efficiency as coolants.

As a contribution of MCHS development and implementation with nanofluids, we report in this study the performance and optimization of a MCHS considering Boron Nitride Nanotubes (BNNTs) nanofluid, its base fluid, a mixture of distilled water and TritonX-100 as surfactant, and distilled water as a reference for two distinct temperatures, $30^{\circ} \mathrm{C}$ and $50^{\circ} \mathrm{C}$ respectively. Such an analysis was never reported before, in particular with this kind of nanoparticles and clearly distinguishing the influence of surfactant and nanoparticles. Also, original experimental data for thermophysical properties are presently used while generally models are often used in the literature to evaluate those properties.

Actually, temperatures can eventually modify the MCHS performance (Reddy and Chamkha, 2016). Although there are microprocessors which work above $100^{\circ} \mathrm{C}$ in industrial computers (Bannatyne, 2016; and VORAGO Technologies, n.d.), such analysis could benefit even for the current commercial industrial microprocessors such as the Intel Xeon microprocessor which recommends its operation at $40^{\circ} \mathrm{C}-60^{\circ} \mathrm{C}$ declared by the company, Intel Corporation (2020) as well as Intel Core $i 7$ microprocessor as reported by Chou (2015), to maintain its temperature at $85^{\circ} \mathrm{C}$ maximum. It is important that modelling analysis of performance from prospective coolants be performed with experimentally obtained properties at potential operating temperatures to provide a reliable outcome before these coolants can be seriously considered in actual applications.

To date, the most common optimization methods for a MCHS are Genetic Algorithm (GA) or Multi-Objective Algorithm (MOGA) which have been utilized by Adham et al. (2012), Halelfadl et al. (2014b), Dokken and Fronk (2018), Wu et al. (2019), and Wang et al. (2020). However, an optimization method has been introduced by Eberhart and Kennedy (1995) which is Particle Swarm Optimization (PSO). Hassan et al. (2005) have tested this PSO method for many design applications and found that the optimization for designs with a strict dimension limit such as a MCHS will favour PSO over GA. In terms of efficiency, Ge et al. (2019) have produced higher range of solutions with a lower time of iterations with MultiObjective PSO (MOPSO) compared to MOGA in mini-channel heat sinks. Comparing MOGA with MOPSO in other applications, the solutions were also much more reliable with MOPSO, as evidenced in thermal acoustic research by Chan et al. (2020).

Therefore, MOPSO will be used in this study for the optimization of the two conflicting objectives that are thermal resistance and pressure drop of a MCHS, for more solutions and reliability. In addition, the dimensions of the walls and channels are taken into consideration in terms of the aspect ratio to find the optimized dimensions of MCHS and numbers of microchannels according to the coolant's properties, as different coolant can lead to different optimized dimensions (Pan et al., 2020). 
The paper is organized as follows. In section 2, the fluids under consideration are presented, as well as their thermophysical properties previously evaluated from full experimental characterization. As mentioned before, we will consider Boron Nitride Nanotubes (BNNTs) nanofluid with nanotube content of $0.001 \mathrm{wt} . \%$, its base fluid, a mixture of distilled water and Triton $\mathrm{X}-100$ as surfactant, and distilled water as a reference, to distinguish the impact of surfactant and nanotubes in MCHS performance. Then, the microchannel heat sink modelling and its validation will be shown in Section 3. Later in section 4, the optimization procedure with MOPSO is presented. Thereafter, the main results of this study are detailed evaluating the cooling performance of the different fluids at two distinct temperatures, 30 and $50^{\circ} \mathrm{C}$, for fixed dimensions of MCHS. Finally, simultaneous minimization of the thermal resistance and pressure drop is shown under optimized channel aspect ratio and channel width ratio for the BNNTs nanofluid $0.001 \mathrm{wt} . \%$ at $30^{\circ} \mathrm{C}$ and $50^{\circ} \mathrm{C}$.

\section{Thermophysical Properties of Fluids}

The base fluid and nanofluid presently considered for the investigation of MCHS optimization and performance were previously comprehensively investigated in terms of stability and thermophysical properties in Gomez-Villarejo et al. (2019). The different fluids considered in the current study are listed and defined in Table 1.

Table 1: Types of fluids studied and their definitions

\begin{tabular}{|l|l|}
\hline Fluids & Definitions \\
\hline Distilled water & Distilled Water $\left(\mathrm{H}_{2} \mathrm{O}\right)$ without any additives \\
\hline TX-100 mix or base fluid & $\begin{array}{l}\text { Distilled Water }\left(\mathrm{H}_{2} \mathrm{O}\right) \text { with } 0.35 \text { vol\% of } \\
\text { surfactant TX-100 }\end{array}$ \\
\hline BNNTs nanofluid 0.001 wt. $\%$ & $\begin{array}{l}\text { Distilled Water }\left(\mathrm{H}_{2} \mathrm{O}\right) \text { with } 0.35 \text { vol\% of } \\
\text { surfactant TX-100 and } 0.001 \text { wt.\% of Boron } \\
\text { Nitride NanoTubes }\end{array}$ \\
\hline
\end{tabular}

All the details about the characterization of BNNT, the characterization of base fluid and nanofluid were fully reported in Gomez-Villarejo et al. (2019). All important information is briefly reported here. The base fluid was prepared using Triton X-100 as surfactant, 0.35 vol.\%, mixed with distilled water. Commercial BNNTs (Sigma-Aldrich@, Saint-QuentinFallavier, France) were dispersed in the base fluid from the two-step method using sonication for 2 hours at room temperature. The data of nanofluids with $0.001 \mathrm{wt} \%$ in BNNTs were presently considered. Density was measured by pycnometry, using a thermal bath for controlling the temperature. The isobaric specific heat was measured using a Temperature Modulated Differential Scanning Calorimetry (TMDSC), using a calorimeter supplied by Netzsch@ (Germany), model DSC214 Polyma. In addition, thermal conductivity was measured by using the laser flash technique (LFA) using a system supplied by Netzsch $\odot$ (Germany), model LFA467 HyperFlash. This technique is able to measure thermal diffusivity, $D$, which can be related to thermal conductivity by using the Standard ASTM E 1461-01. Shear flow curves and dynamic viscosity were evaluated from Kinexus Pro rheometer under steady-state conditions and with cone and plate geometry. All the measured properties at $30^{\circ} \mathrm{C}$ 
and $50^{\circ} \mathrm{C}$ presently used are gathered in Table 2. Overall, it is observed that the thermophysical properties of water are increased by the presence of surfactant and BNNTs respectively. The thermal conductivity and isobaric specific heat increase with temperature while density and viscosity decrease as expected.

Table 2: Properties of distilled water, TX-100 mix and BNNTs nanofluids $0.001 \mathrm{wt} . \%$ at $30^{\circ} \mathrm{C}$ and $50^{\circ} \mathrm{C}$

\begin{tabular}{|l|c|c|c|c|}
\hline \multicolumn{5}{|c|}{ Properties at 30 ${ }^{\circ} \mathbf{C}$} \\
\hline Distilled Water & $\mathrm{k}(\mathrm{W} / \mathrm{mK})$ & $\rho\left(\mathrm{kg} / \mathrm{m}^{3}\right)$ & $\mathrm{Cp}(\mathrm{J} / \mathrm{kg} . \mathrm{K})$ & $\mu\left(\mathrm{Ns} / \mathrm{m}^{2}\right)$ \\
\hline TX-100 mix & 0.536 & 997.0 & 4.017 & 0.756 \\
\hline $\begin{array}{l}\text { BNNTs nanofluid } \\
\text { 0.001 wt. \% }\end{array}$ & 0.543 & 997.1 & 4.065 & 0.809 \\
\hline \multicolumn{5}{|c|}{ Properties at 50 $\mathbf{C}$} \\
\hline Distilled Water
\end{tabular}

\section{Microchannel heat sink modelling and validation}

Figure 1 is the schematic of a MCHS that was first introduced by Tuckerman and Pease (1981) and redrawn by Adham et al. (2012). The material of the MCHS is made of silicon which is also the base of the MCHS that is attached on top of the microprocessor. The top layer is an adiabatic cover to prevent vertical heat loss and to ensure the effectiveness of the system.

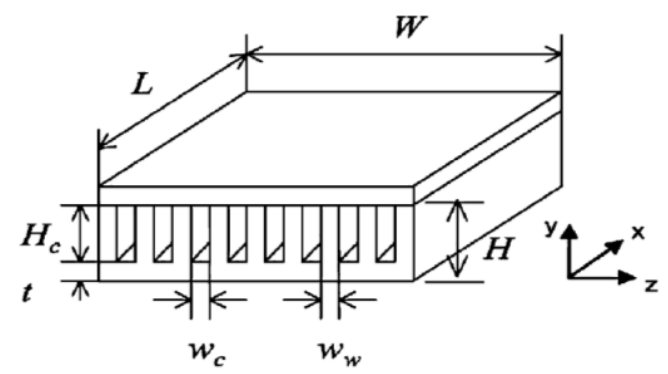

Figure 1: Schematic structure of a rectangular cross section MCHS (Adham et al., 2012)

The design parameters of the MCHS in Figure 1 are listed in Table 3.

Table 3: Design parameters of MCHS 


\begin{tabular}{|l|l|l|l|}
\hline MCHS Total Width & $W$ & Channel Height & $H_{c}$ \\
\hline MCHS Total Height & $H$ & Channel Width & $w_{c}$ \\
\hline MCHS Total Length & $L$ & Wall Width & $w_{w}$ \\
\hline Thickness of base & $t$ & & \\
\hline
\end{tabular}

The design variables, the channel aspect ratio, $\alpha$ and channel width ratio, $\beta$ that are managed for the optimization of a MCHS, are defined as (Adham et al., 2012):

$$
\begin{gathered}
\alpha=\frac{H_{c}}{w_{c}} \\
\beta=\frac{w_{w}}{w_{c}}
\end{gathered}
$$

The performance of MCHS is evaluated by its thermal and pressure drop performance. Heat and flow conditions in the theoretical model are considered in steady state and under developed laminar flow with constant thermophysical properties. The thermal performance of a MCHS is described by its total thermal resistance consisting of the thermal resistance from the heat source to the top of the MCHS base, the resistance to heat from the MCHS base and wall of the microchannel to the coolant via convection and the capacitance resistance of the fluid itself. The total is expressed from the model developed by Tuckerman \& Pease (1981):

$$
R_{\text {Total }}=R_{\text {Conductive }}+R_{\text {Convective }}+R_{\text {Capacitive }}
$$

where each resistance is defined as follow,

$$
\begin{aligned}
& R_{\text {conductive }}=\frac{t}{k_{h s}} \\
& R_{\text {convective }}=\frac{1}{h_{a v}} \frac{1+\beta}{1+2 \alpha \eta} \\
& R_{\text {capacitive }}=\frac{L}{C p_{f} \mu_{f}} \frac{2}{\operatorname{Re}} \frac{1+\beta}{1+\alpha}
\end{aligned}
$$

In the previous equations, $k_{h s}$, is the thermal conductivity of the heat sink, $C_{p f}$, is the specific heat capacity of the fluid, $\mu_{f}$ is the viscosity of the fluid, $\eta$, is the efficiency of the microchannel wall utilizing adiabatic fin equation, $R e$, is the Reynold number and $h_{a v}$, is the average heat transfer coefficient which is calculated via the correlation proposed by Kim and Kim (1999) considering the thermal conductivity of fluid, $k_{f}$. The Reynold number, $R e$, and average heat transfer coefficient, $h_{a v}$ are defined as, 


$$
\begin{aligned}
& \operatorname{Re}=\frac{2 \rho_{f} G}{\mu_{f} n H_{c}} \cdot \frac{\alpha}{\alpha+1} \\
& h_{a v}=\frac{N u k_{f}}{D_{h}}
\end{aligned}
$$

where the Nusselt number, $N u$, and the hydraulic diameter, $D_{h}$, are defined respectively as

$$
\begin{aligned}
& N u=2.253+8.164\left(\frac{\alpha}{\alpha+1}\right)^{3 / 2} \\
& D_{h}=\frac{4 H_{c} w_{c}}{2\left(H_{c}+w_{c}\right)}
\end{aligned}
$$

The fin efficiency, $\eta$, is calculated based on fin theory as

$$
\eta=\frac{\tanh \left(m H_{c}\right)}{m H_{c}}
$$

and $m$ is the fin parameter given by the following equation.

$$
m=\sqrt{\frac{2 h_{a v g}}{k_{f} w_{w}}}
$$

The heat source is assumed to be homogeneously spread throughout the silicon base of the MCHS and is transferred to the microchannels directly by the thickness of the base. Conductivity of silicon below $1000 \mathrm{~K}$ is expressed by the following formula by Prakash (1978) and validated through experimental results of Glassbrenner and Slack (1964):

$$
k_{h s}=k_{h s, \text { ambient }}\left[1-1.093\left(\frac{T_{h s}-T_{h s, \text { ambient }}}{T_{h s}}\right)^{0.8705}\right]
$$

Reaching the microchannel surfaces directly and indirectly via base and fins along the microchannels, the heat source transferred via convection is affected by the efficiency of the fins. The heat is then stored by the fluid's capacitance or properties which is expressed as the capacitive resistance.

The pressure drop, $\Delta P$, related to the hydrodynamic performance is calculated via relationships that have been developed by Knight et al. (1992), Kleiner et al. (1995), Copeland (2000), and Adham et al. (2012);

$$
\Delta P_{\text {Total }}=\Delta P_{\text {Laminar }}+\Delta P_{\text {Constriction \& Expansion }}
$$


with each pressure drop term defined as,

$$
\begin{aligned}
& \Delta P_{\text {Constriction \& Expansion }}=\left[1.79-2.32\left(\frac{1}{1+\beta}\right)+0.53\left(\frac{1}{1+\beta}\right)\right] \rho_{f}\left(\frac{v^{2}}{2}\right) \\
& \Delta P_{\text {Laminar }}=f_{a p p}\left[\frac{(1+\alpha)}{2 H_{c}} \rho_{f} \frac{v^{2}}{2}\right]+\left[1.8-2.4\left(\frac{1}{1+\beta}\right)+0.6\left(\frac{1}{1+\beta}\right)\right] \rho_{f}\left(\frac{v^{2}}{2}\right)
\end{aligned}
$$

where $f_{\text {app }}$ is the friction factor caused by the developing and developed flow regions defined as,

$$
f_{a p p}=\frac{1}{\operatorname{Re}}\left\{\left[3.2\left(\frac{\operatorname{Re} D_{h}}{x}\right)^{0.52}\right]^{2}+(18.8+78.57 B)^{2}\right\}^{0.5}
$$

In the previous equation, B is the geometrical factor defined by Bejan (1995),

$$
B=\frac{\left(\frac{1}{\alpha}\right)^{2}+1}{\left(\frac{1}{\alpha}+1\right)^{2}}
$$

\subsection{Validation}

The validation process consists of comparisons of the outcomes of the current model with all the experimental results from the landmark study by Tuckerman and Pease (1981). Tuckerman and Pease (1981) designed their microchannels with three different sizes due to manufacturing tolerance denoted model A, B and C respectively in Table 4 . These differences in dimensions have been expressed in terms of $\alpha$ and $\beta$ variation in Table 5. Table 4 and Table

\begin{tabular}{|c|c|c|c|c|c|c|}
\hline \multicolumn{7}{|c|}{ Parameters } \\
\hline & \multicolumn{6}{|c|}{ Author } \\
\hline & $\mathrm{T} \& \mathrm{P}$ & Current & $\mathrm{T} \& \mathrm{P}$ & Current & $\mathrm{T} \& \mathrm{P}$ & Current \\
\hline Model & \multicolumn{2}{|r|}{$\mathrm{A}$} & \multicolumn{2}{|r|}{$\mathrm{B}$} & \multicolumn{2}{|r|}{$\mathrm{C}$} \\
\hline $\mathrm{H}_{\mathrm{c}}(\mu \mathrm{m})$ & \multicolumn{2}{|r|}{287} & \multicolumn{2}{|r|}{302} & \multicolumn{2}{|r|}{320} \\
\hline $\mathrm{w}_{\mathrm{c}}(\mu \mathrm{m})$ & \multicolumn{2}{|r|}{55} & \multicolumn{2}{|r|}{50} & \multicolumn{2}{|r|}{56} \\
\hline $\mathrm{w}_{\mathrm{w}}(\mu \mathrm{m})$ & \multicolumn{2}{|r|}{45} & \multicolumn{2}{|r|}{50} & \multicolumn{2}{|r|}{44} \\
\hline $\mathrm{t}(\mu \mathrm{m})$ & \multicolumn{2}{|r|}{143} & \multicolumn{2}{|r|}{256} & \multicolumn{2}{|r|}{213} \\
\hline $\mathrm{V}(\mathrm{m} / \mathrm{s})$ & \multicolumn{2}{|r|}{4.1} & \multicolumn{2}{|r|}{5.4} & \multicolumn{2}{|r|}{2.6} \\
\hline $\mathrm{Re}$ & \multicolumn{2}{|r|}{501} & \multicolumn{2}{|r|}{644} & \multicolumn{2}{|r|}{330} \\
\hline
\end{tabular}
5 list the parameters used by Tuckerman and Pease (1981) and validation of thermal resistance and pressure drop obtained from equations (1) to (18) respectivley.

Table 4: Parameters with that of Tuckerman and Pease (T\&P, 1981) 


\begin{tabular}{|l|c|c|c|}
$\mathrm{Nu}$ & 8.53 & 8.74 & 8.66 \\
\hline $\mathrm{h}_{\mathrm{av}}(\mathrm{W} / \mathrm{mK})$ & 49524 & 54608 & 48713 \\
\hline $\mathrm{D}_{\mathrm{h}}(\mu \mathrm{m})$ & 92.3 & 85.8 & 95.3 \\
\hline$\eta$ & 0.73 & 0.71 & 0.68 \\
\hline $\mathrm{B}$ & 0.73 & 0.76 & 0.75 \\
\hline
\end{tabular}


Table 5: Validation with that of Tuckerman and Pease (T\&P, 1981)

\begin{tabular}{|l|c|c|c|c|c|c|}
\hline \multirow{2}{*}{} & \multicolumn{6}{|c|}{ Validation } \\
\cline { 2 - 8 } & T\&P & Current & T\&P & Current & T\&P & Current \\
\hline Model & \multicolumn{2}{|c|}{ A } & \multicolumn{2}{|c|}{$\mathrm{B}$} & \multicolumn{2}{c|}{$\mathrm{C}$} \\
\hline $\mathrm{H}_{\mathrm{c}}(\mu \mathrm{m})$ & \multicolumn{2}{|c|}{287} & \multicolumn{2}{c|}{302} & \multicolumn{2}{c|}{320} \\
\hline$\alpha$ & \multicolumn{2}{|c|}{5.2182} & \multicolumn{2}{c|}{6.04} & \multicolumn{2}{c|}{5.7143} \\
\hline$\beta$ & \multicolumn{2}{|c|}{1} & \multicolumn{2}{c|}{0.8182} & \multicolumn{2}{c|}{0.7857} \\
\hline $\mathrm{R}_{\mathrm{th}}(\mathrm{W} / \mathrm{K})$ & 0.113 & 0.092 & 0.090 & 0.085 & 0.110 & 0.110 \\
\hline$\Delta \mathrm{P}(\mathrm{psi})$ & 17 & 21.1 & 31 & 35.1 & 15 & 12.6 \\
\hline error $\mathrm{R}_{\mathrm{th}}(\%)$ & - & $18.7 \%$ & - & $5.08 \%$ & - & $0.27 \%$ \\
\hline error $\Delta \mathrm{P}(\%)$ & - & $24.1 \%$ & - & $13.3 \%$ & - & $15.9 \%$ \\
\hline
\end{tabular}

According to Table 4, it can be seen that each model has different microchannel dimensions and flow velocity, affecting heat transfer parameters and flow condition. Table 5 shows validation result yielding distinct differences ranging from $0.13 \%$ to $18.73 \%$ for the thermal resistance and $13.33 \%$ to $24.07 \%$ for the pressure drop. A quite good agreement between $\mathrm{T} \& \mathrm{P}$ and present study for both the thermal resistance and pressure drop is found with model B with a channel height, $\underline{H}_{c}$, of $302 \mu \mathrm{m}$. The deviation can be explained by the different properties of coolants used. In Tuckerman and Pease (1981), deionized water at $23^{\circ} \mathrm{C}$ was studied while in this study the properties of distilled water were considered at $30^{\circ} \mathrm{C}$, as gathered in Table 2. Based on this result, the dimensions according to model B was chosen in the current study to evaluate the performance of MCHS using experimental thermophysical properties of the fluids, as described in the following. The channel height, $H_{c}$, of the microchannel remained constant at $302 \mu \mathrm{m}$ throughout the study including in optimization associated with aspect ratio, $\alpha$, as in equation (1).

\section{Optimization Procedure}

Thermal resistance, $R_{t h}$, and pressure drop, $\Delta P$, are two conflicting objectives in enhancing the performance of a MCHS. MOPSO algorithm and coding were adapted from Mohammad (2011) to describe the performance through the function for thermal resistance and pressure drop following equation (3) and (14), respectively. Two design variables, aspect ratio, $\alpha$, and width ratio, $\beta$, as defined in equation (1) and (2) respectively were set to the limits shown in Table 4 with a constant channel height, $H_{c}$, at $302 \mu \mathrm{m}$.

Table 6: Lower and Upper Limits of the design variables.

\begin{tabular}{|c|c|c|}
\hline Design Variables & Lower Limits & Upper Limits \\
\hline$\alpha$ & 1 & 6.04 \\
\hline$\beta$ & 0.10 & 1 \\
\hline
\end{tabular}

The limits of aspect ratio, $\alpha$, only extend channel width, $w_{c}$, from $50 \mu \mathrm{m}$ to be expended to a fixed size of the channel height, $H_{c}$, at $302 \mu \mathrm{m}$. $50 \mu \mathrm{m}$ was chosen to be the 
minimum channel width to ease the comparison with the pioneer dimension of that MCHS by Tuckerman and Pease (1981) to highlight the coolant's thermal performance. While width ratio, $\beta$, limits the minimum of channel width, $w_{w}$, to $5 \mu \mathrm{m}$ according to flexure width done by Chan et al. (2006). Current micromachining and etching limitation do surpass $5 \mu \mathrm{m}$ but it is prone to defect such as scalloping and researches were mostly focused on microchannel or trench dimension rather than its wall (Kiihamäki \& Franssila, 1999; Chan et al., 2006; Chen et al., 2007; Lindroos et al. (2010); Lips \& Puers, 2016; Tang et al., 2018). The lower and upper limits of the design variables are the maximum and minimum size for channel width, $w_{c}$, and wall width, $w_{w}$, for the microchannels with a constant channel height, $H_{c}$. Utilizing MOPSO optimization, aspect ratio, $\alpha$, and width ratio, $\beta$, adhere to the main equation of particle swarm as follows,

$$
\begin{aligned}
& v_{t+1}=\text { weight } \cdot v_{t}+C_{1} \cdot\left(p_{\text {best }}-x_{t}\right)+C_{2} \cdot\left(g_{\text {best }}-x_{t}\right) \\
& x_{t+1}=x_{t}+v_{t+1}
\end{aligned}
$$

Where $x$ is the position of the particle randomly placed initially in 2-dimensional space of $\mathrm{x}$-axis and $\mathrm{y}$-axis representing $\alpha$ and $\beta$, and $v$ is the velocity of the particle. The subscript $t$ is the initial or current iteration and $t+1$ is the next iteration. As each swarm particle in MOPSO was positioned randomly following the limits and changes of their velocity at every iteration, the velocity was guided by best particle referred by every individual particle, $p_{\text {best }}$, best particle referred by all or global particle, $g_{\text {best }}$, and particles' own velocity.

According to Clerc (1999), acceleration known as $C_{1}$ and $C_{2}$ was added to adjust $p_{\text {best }}$ and $g_{\text {best }}$ velocity, respectively finer particle dispersion which later also appended with weight to adjust its own velocity for a better solution by Eberhart and Shi (2001). The weight, $C_{1}$ and $C_{2}$ were obtained by test and error and according to Clerc (1999). This adjustment via weight and acceleration ensures that the particles pass the good solution area and are not too small for better regions left unexplored. The weight, $C_{1}$, and $C_{2}$ were set as in Table 7 .

Table 7: weight and acceleration range.

\begin{tabular}{|c|c|}
\hline Velocity Adjuster & Range \\
\hline weight & $0.1-1$ \\
\hline $\mathrm{C}_{1}$ & 1.5 \\
\hline $\mathrm{C}_{2}$ & 1.5 \\
\hline
\end{tabular}

With the structured algorithm, pareto front will be generated with both objective functions and every solution produced will dictate a different design of a MCHS according to the desired thermal resistance and pressure drop. The fundamental steps of a MOPSO are shown in Figure 2. In this study, position of the swarm particles resembles the dimension of a microchannel via aspect ratio, $\alpha$, and width ratio, $\beta$. 


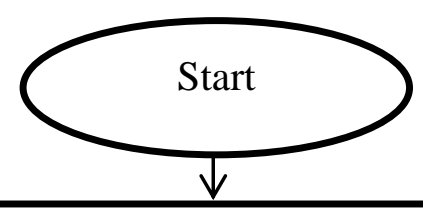

Setting up problem and constraints

Initializing the parameters with velocity adjuster $\left(w, C_{1}\right.$ and $\left.C_{2}\right)$

$$
\downarrow
$$

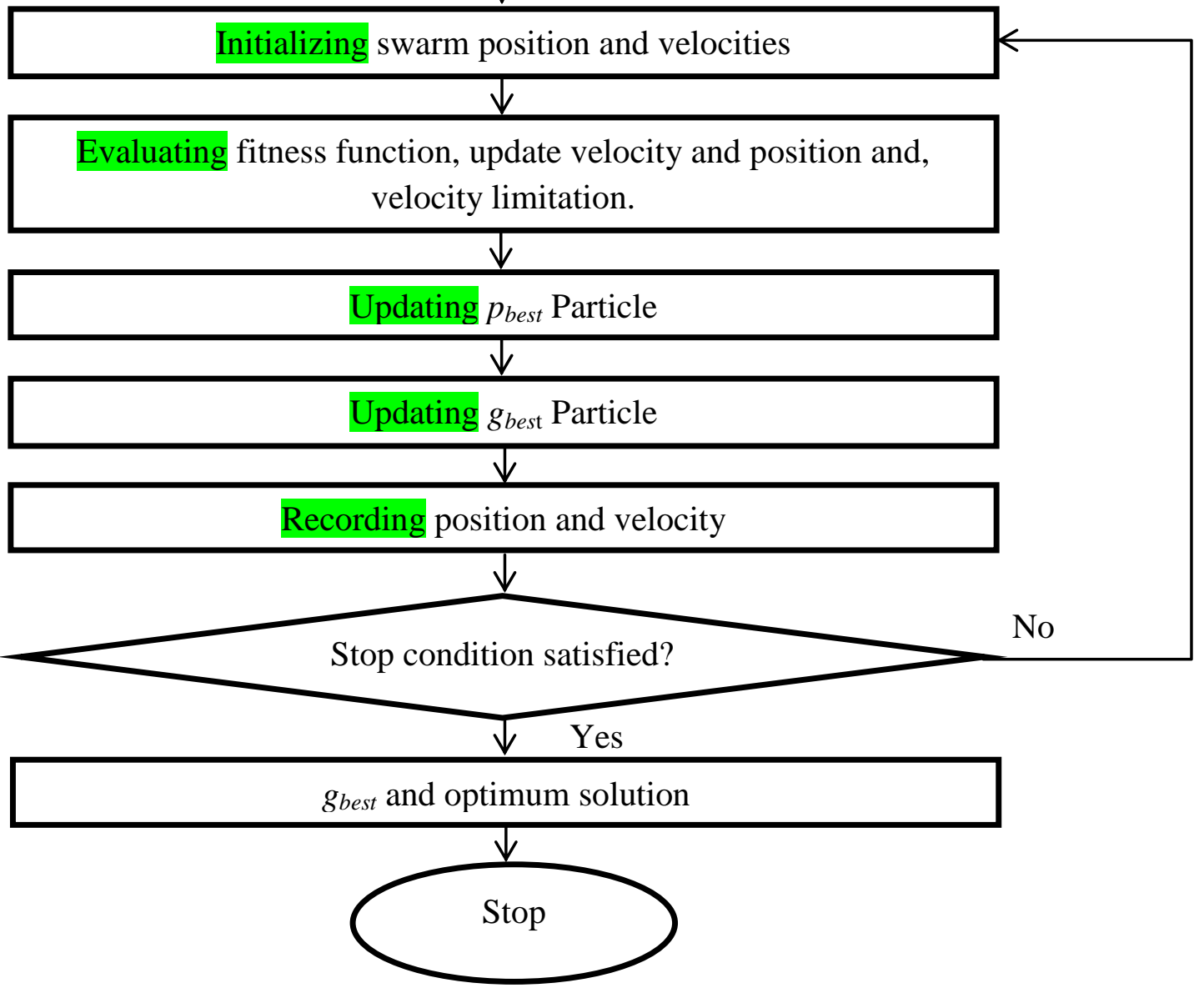

Figure 2: Multi-Objective Particle Swarm Optimization (MOPSO) Flowchart 


\section{Results and Discussions}

\subsection{Analysis of coolant performance}

To study the effects of the surfactant TX-100 and the content of BNNTs on the thermal resistance and pressure drop, the results are compared to those with distilled water, including the effect of temperatures, $30^{\circ} \mathrm{C}$ and $50^{\circ} \mathrm{C}$. These theoretical data of thermal resistance and pressure drop were obtained by substituting the thermophysical properties of all three fluids into the relevant equations with the dimensions of model B. Figure 3 is the bar chart of the thermal resistance and pressure drop for all three fluids to show clearly the impact of the presence of the surfactant TX-100 and BNNTs compared to distilled water. Table 8 includes the percentage difference compared to distilled water $\left(\mathrm{H}_{2} \mathrm{O}\right)$ following equation (21) where $z$ is the thermal resistance or pressure drop of base fluid and BNNTs nanofluid $0.001 \mathrm{wt} . \%$, and $y$ is the thermal resistance or pressure drop of distilled water.

$$
c f . \%=\frac{z-y}{y} \times 100
$$

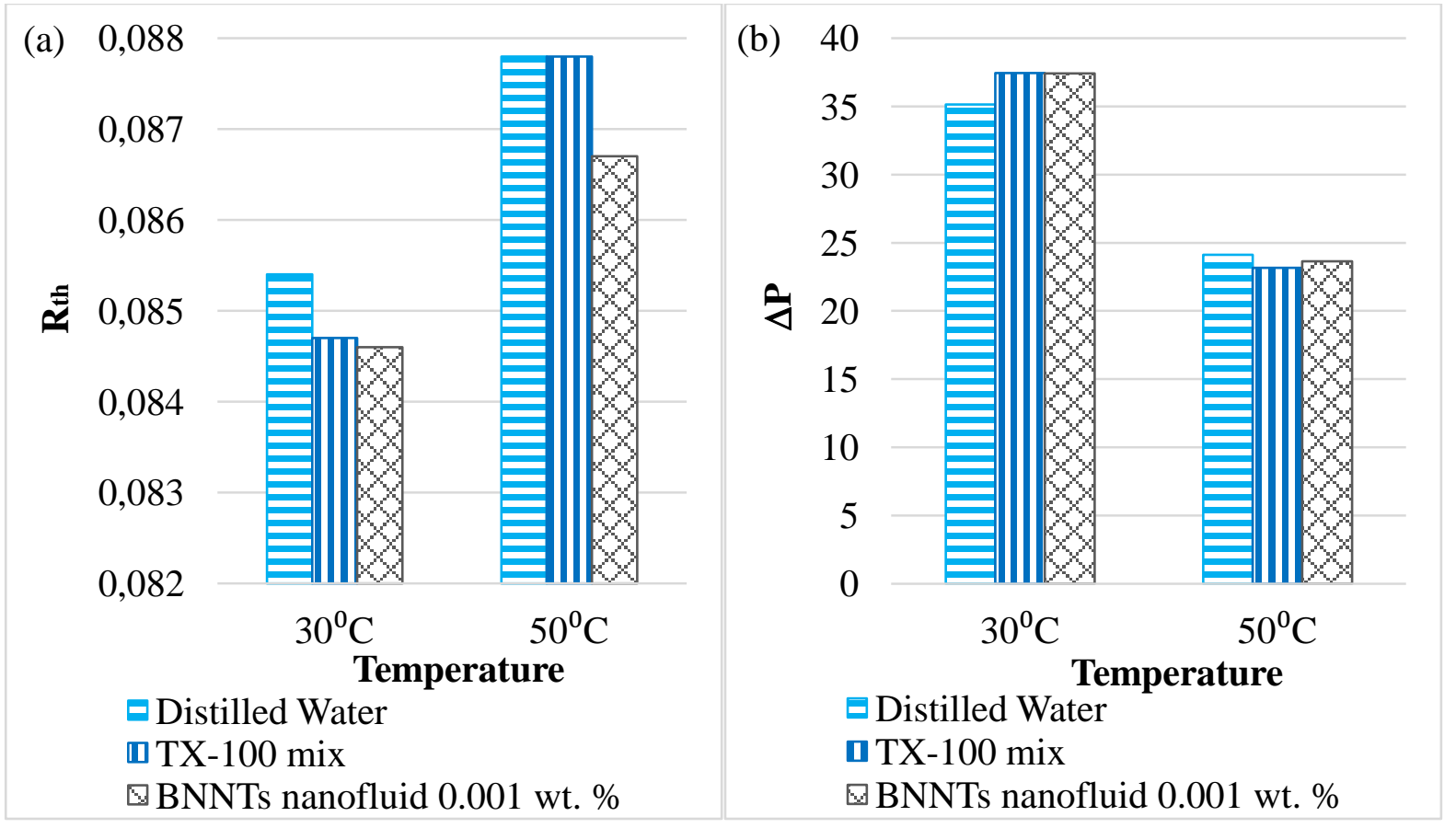

Figure 3: Thermal resistance, $R_{t h}$, and pressure drop, $\Delta P$, for the different fluids at $30^{\circ} \mathrm{C}$ and $50^{\circ} \mathrm{C}$ 
Table 8: Thermal resistance, $R_{t h}$, and pressure drop, $\Delta P$, for all fluids

\begin{tabular}{|l|c|c|c|c|c|c|}
\hline & \multicolumn{3}{|c|}{ Thermal Resistance, $\mathbf{R}_{\text {th }}(\mathbf{K} / \mathbf{W})$} & \multicolumn{3}{c|}{ Pressure Drop, $\Delta$ P (psi) } \\
\hline Fluid & $\begin{array}{c}\text { Distilled } \\
\text { Water } \\
\left(\mathrm{H}_{2} \mathrm{O}\right)\end{array}$ & $\begin{array}{c}\mathrm{TX}-100 \\
\text { mix }\end{array}$ & $\begin{array}{c}\text { BNNTs } \\
\text { nanofluid } \\
0.001 \\
\text { wt. } \%\end{array}$ & $\begin{array}{c}\text { Distilled } \\
\text { Water } \\
\left(\mathrm{H}_{2} \mathrm{O}\right)\end{array}$ & $\begin{array}{c}\text { TX-100 } \\
\text { mix }\end{array}$ & $\begin{array}{c}\text { BNNTs } \\
\text { nanofluid } \\
0.001 \\
\text { wt.\% }\end{array}$ \\
\hline $30^{0} \mathrm{C}$ & 0.0854 & 0.0847 & 0.0846 & 35.1 & 37.5 & 37.4 \\
\hline $50^{0} \mathrm{C}$ & 0.0878 & 0.0878 & 0.0867 & 24.1 & 23.2 & 23.6 \\
\hline $\begin{array}{l}30^{0} \mathrm{C}- \\
\text { percentage } \\
\text { difference } \\
\text { compared to } \\
\mathrm{H} 2 \mathrm{O} \text {. }\end{array}$ & - & $-0.82 \%$ & $-0.94 \%$ & - & $6.62 \%$ & $6.50 \%$ \\
\hline $\begin{array}{l}50^{0} \mathrm{C}- \\
\text { percentage } \\
\text { difference } \\
\begin{array}{l}\text { compared to } \\
\text { H2O. }\end{array}\end{array}$ & - & $0.00 \%$ & $-1.25 \%$ & - & $-3.96 \%$ & $-1.97 \%$ \\
\hline
\end{tabular}

Generally, the thermal resistance is high at a higher temperature for all types of fluids investigated here, an increase between $2.5 \%$ to $3.7 \%$ from $30^{\circ} \mathrm{C}$ to $50^{\circ} \mathrm{C}$ is noticed. Compensating for the high thermal resistivity, all coolants from $30^{\circ} \mathrm{C}$ to $50^{\circ} \mathrm{C}$ have a significant lower pressure, lowered by $32 \%$ to $38 \%$ compared to that at $30^{\circ} \mathrm{C}$. The thermal resistance and pressure drop are well established to have conflicting effects on each other, an increase in one, results in a decrease in the other.

At $30^{\circ} \mathrm{C}$, adding surfactant TX-100 into distilled water decreases the thermal resistance by $0.82 \%$. The thermal conductivity and heat capacity of TX-100 mix is higher than water by $0.007 \mathrm{~W} / \mathrm{mK}$ and $0.0481 \mathrm{~J} / \mathrm{kg} . \mathrm{K}$, respectively, lowering the capacitance resistance. Referring to Table 2, the viscosity increases, directly increasing the friction factor and pressure drop. This is aligned with the statement of Garg et al. (2015), Xia et al. (2016), and Ghasemi et al. (2017), a surfactant might impact a MCHS performance as different types of surfactant will change the coolant's properties accordingly. In this study, it is clear that the presence of surfactant TX-100 in water already lowers the thermal resistivity at $30^{\circ} \mathrm{C}$. Addition of BNNTs at 0.001 wt.\% increases both the thermal conductivity and heat capacity each by $1.5 \%$, in agreement with various reports utilizing nanofluid as coolant; Hasan (2014)and Azizi et al. (2016). Nevertheless, the thermal performance difference between base fluid and BNNTs nanofluid $0.001 \mathrm{wt} . \%$ is only about $0.12 \%$, quite insignificant.

As adding TX-100 to distilled water decreases thermal resistance, it also increases the pressure drop by $6.62 \%$ due to the increase of density and viscosity. Low content in BNNTs actually reduces both thermal resistance and pressure drop for the same amount of $0.12 \%$ as compared to base fluid as shown in Table 8. Although the improvisation is quite insignificantly low for only $0.12 \%$ difference for both conflicting objectives of thermal 
resistance and pressure drop, in normal circumstances the presence of nanotubes or nanoparticles in base fluid for MCHS applications usually improve thermal resistance with the consequence of degrading pressure drop. Referring to equation (15) to equation (17), pressure drop is influenced by viscosity, $\mu$, through Reynold number, $R e$, from equation (7) and density, $\rho$. The mentioned properties in Table 2 indicate that nanofluid with $0.001 \mathrm{wt} . \%$ in BNNTs has higher density compared to base fluid with viscosity only lowered by 0.001 $\mathrm{Ns} / \mathrm{m}^{2}$. In term of pressure drop with the same microchannel dimension for MCHS, viscosity plays a larger role on hydrodynamic performance compared to density affecting apparent friction factor, $f_{\text {app }}$.

At $50^{\circ} \mathrm{C}$, where all fluids have a higher thermal conductivity up to $0.567 \mathrm{~W} / \mathrm{mK}$ compared to that at $30^{\circ} \mathrm{C}$, all fluids are expected to have a lower thermal resistance. However, since there was a significant drop of base's conductivity for silicon, heat capacity, $C_{p}$, and viscosity, $\mu$, for all the fluids, thermal resistance eventually increases up to $0.0878 \mathrm{~K} / \mathrm{W}$ for both distilled water and base fluid, and $0.0867 \mathrm{~K} / \mathrm{W}$ for BNNTs nanofluid 0.001wt.\%. Increment of fluid conductivity might have increased the heat transfer coefficient, $h$, that improves the convective resistance, $R_{\text {conv }}$, but the significant increase in the thermal resistance at $50^{\circ} \mathrm{C}$ was driven by the coolant's heat capacity resistance and conductive resistance. Fluid capacity resistance, $R_{\text {cap }}$, is a result of two major factors; heat capacity, $C_{p}$, and viscosity, $\mu$, as given in equation (6) as well as the effect of decreasing viscosity which increases the Reynolds number, $R e$. The conductive resistance, $R_{\text {cond, }}$ will have a huge spike as the conductivity, $k_{b}$, of silicon base drops from $148 \mathrm{~W} / \mathrm{mK}$ to $131.7 \mathrm{~W} / \mathrm{mK}$ at $50^{\circ} \mathrm{C}$. The low viscosity has led to a higher thermal resistance which consequently also contributes greatly towards a decrease in the pressure drop as shown in Figure 3.

Referring to Table 2, the base fluid acquired a higher heat capacity and lower thermal conductivity compared to distilled water at $50^{\circ} \mathrm{C}$. But in Figure 3 and Table 8, the results show no change in its thermal resistance as it was outweighed due the decrease in viscosity. The balance in the thermophysical properties changes by adding surfactant TX-100 into distilled water have no improvement nor degradation of the fluid performance. With the reduction of viscosity, base fluid pressure drop was decreased by $3.96 \%$ at $50^{\circ} \mathrm{C}$. It is observed that the presence of surfactant TX-100 has no impact on the thermal resistance. BNNTs nanofluid $0.001 \mathrm{wt} \%$ shows a significant drop in thermal resistance compared to water and base fluid, improved by $1.25 \%$. Adding nanotubes and surfactant is expected to increase the pressure drop. However, in this case, surfactant TX-100 positively impacts the properties which reduces the pressure drop. The presence of BNNTs increases the pressure drop due to the increase in nanofluid viscosity compared to base fluid.

However, at $50^{\circ} \mathrm{C}$, adding Triton X-100 surfactant into distilled water has no impact on thermal resistance but definitely benefits on improving the pressure drop. The use of BNNTs nanofluid $0.001 \mathrm{wt}$.\% improves the thermal resistance with a slight increase in pressure drop compared to TX-100 mix but still lower than distilled water. Therefore, use of nanofluid already leads to improve a $1 \mathrm{~cm} \times 1 \mathrm{~cm}$ MCHS performance with both lower thermal resistance and pressure drop compared to distilled water with the same microchannel dimension. 
The preceding section reports the theoretical outcomes of the performance analysis when all the parameters are fixed as in Model B. Next, simultaneous minimization of the thermal resistance and pressure drop is completed under optimized channel aspect ratio, $\alpha$, and channel width ratio, $\beta$, for the BNNTs nanofluid $0.001 \mathrm{wt} . \%$. The channel aspect ratio, $\alpha$, and channel width ratio, $\beta$, are set in the range limit as in Table 6 describing the geometry restriction referred in equation (1) and (2) which MOPSO search for the optimized values in those range such that both the thermal resistance and pressure drop are simultaneously minimized. This is done to explore cooling possibilities in attaining both the conflicting objectives; low thermal resistance as well as low pressure drop. This reduction can be done by adjusting the dimensions of the MCHS. Different fluids will be expected to run best at different geometry according to their properties. The pareto front shown in Figure 4 exhibits the optimization results obtained by manipulating the channel and wall width via the aspect ratio with a constant channel height of $302 \mu \mathrm{m}$, a maximum of one hundred iterations and minimum of ten repetitions. The red rectangle indicates the best thermal performance acquiring the lowest resistance, consequently at the highest pressure drop. Green circle on the other hand shows the balance of both thermal resistance and pressure drop. The two solution sets depend on the desire of implementations either for only maximum heat removal or with economic consideration as well, as pressure drop stipulates power consumption. Each of the points in the chart yields a specific dimension set of the channel and wall width of the MCHS. The dimensions reaching the optimized result output of the MCHS, however, must comply with the limits of the tolerance and capability of manufacturing or etching type during a MCHS production.

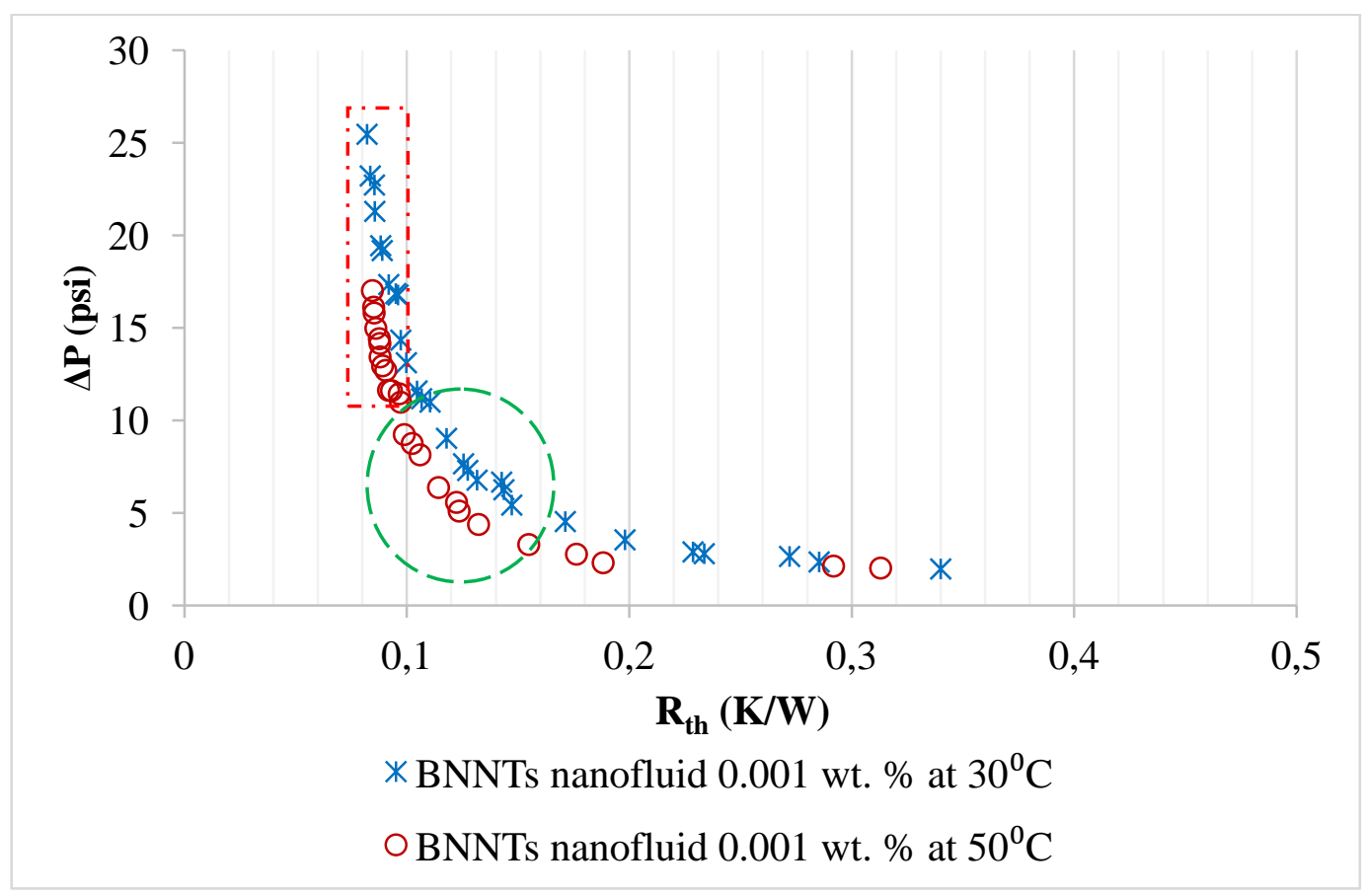

Figure 4: Pareto front of BNNTs nanofluid 0.001wt. $\%$ using MOPSO at $30^{\circ} \mathrm{C}$ and $50^{\circ} \mathrm{C}$ 
Table 9 lists the comparison of the thermal resistance and pressure drop $\left(R_{t h}\right.$ and $\left.\Delta P\right)$ extracted from the pareto front in green circle with that of the theoretical values for BNNTs nanofluid $0.001 \mathrm{wt} . \%$ for both temperatures of $30^{\circ} \mathrm{C}$ and $50^{\circ} \mathrm{C}$. The reduction and increment of optimized results are calculated using Equation (21) with $z$ now being the optimized value and $y$ the theoretical one for BNNTs nanofluid $0.001 \mathrm{wt} . \%$.

Table 9: Balanced thermal resistance, $R_{t h}$, and pressure drop, $\Delta P$

\begin{tabular}{|c|c|c|c|c|c|c|c|c|}
\hline & \multicolumn{4}{|c|}{$\begin{array}{l}\text { BNNTs nanofluid } 0.001 \text { wt. } \% \text { at } \\
3^{\circ} \mathrm{C}\end{array}$} & \multicolumn{4}{|c|}{$\begin{array}{l}\text { BNNTs nanofluid } 0.001 \text { wt. \% at } \\
50^{\circ} \mathrm{C}\end{array}$} \\
\hline No. & $\mathrm{R}_{\mathrm{th}}(\mathrm{W} / \mathrm{K})$ & $\Delta \mathrm{P}(\mathrm{psi})$ & $\begin{array}{c}\mathrm{R}_{\mathrm{th}} \mathrm{cf} . \\
(\%)\end{array}$ & $\begin{array}{c}\Delta \mathrm{P} \mathrm{cf} . \\
(\%)\end{array}$ & $\mathrm{R}_{\mathrm{th}}(\mathrm{W} / \mathrm{K})$ & $\Delta \mathrm{P}(\mathrm{psi})$ & $\begin{array}{c}\mathrm{R}_{\mathrm{th}} \mathrm{cf} . \\
(\%)\end{array}$ & $\begin{array}{c}\Delta \mathrm{P} c f \\
(\%)\end{array}$ \\
\hline 1 & 0.147 & 5.43 & 74.0 & -85.5 & 0.155 & 3.30 & 78.6 & -86.0 \\
\hline 2 & 0.144 & 6.26 & 69.9 & -83.3 & 0.132 & 4.39 & 52.6 & -81.4 \\
\hline 3 & 0.143 & 6.68 & 68.7 & -82.2 & 0.124 & 5.11 & 42.5 & -78.4 \\
\hline 4 & 0.132 & 6.78 & 55.6 & -81.9 & 0.122 & 5.58 & 41.2 & -76.4 \\
\hline 5 & 0.127 & 7.30 & 50.6 & -80.5 & 0.114 & 6.38 & 31.9 & -73.0 \\
\hline 6 & 0.126 & 7.66 & 48.4 & -79.5 & 0.106 & 8.15 & 22.2 & -65.5 \\
\hline 7 & 0.118 & 9.04 & 39.4 & -75.8 & 0.103 & 8.76 & 18.2 & -62.9 \\
\hline
\end{tabular}

The seven selected solutions for both temperatures show a decrease in the pressure drop by up to more than $80 \%$ with the consequence of an increase in the thermal resistance by up to more than $70 \%$. Compared to the theoretical values, the pressure drop decreases from 37.4 psi to 5.4 psi at $30^{\circ} \mathrm{C}$ and 23.6 psi to 3.3 psi at $50^{\circ} \mathrm{C}$. Although the thermal resistances listed increased greatly by $18.2 \%$ to $78.6 \%$, the other objective which is the pressure drop reduced tremendously indicating possibilities in energy saving in low heat removal applications. To find the best MCHS performance with the lowest values in thermal resistance, solutions in red rectangle from Figure 4 are discussed in the following.

Table 10 lists the comparison for lowest thermal resistance and corresponding pressure drop extracted from the pareto front for BNNTs nanofluid $0.001 \mathrm{wt}$. $\%$ for six extracted results. As previously, the reduction and increment of optimized results are calculated using Equation (21) with $z$ the optimized value and $y$ the theoretical one for BNNTs nanofluid $0.001 \mathrm{wt} . \%$. These results are taken from the red box in Figure 4. The possibilities involve:

a) Lower thermal resistance and pressure drop.

b) Higher thermal resistance with a greater decrease in pressure drop. 
Table 10: Minimum thermal resistance, $R_{t h}$, and associated pressure drop, $\Delta P$

\begin{tabular}{|c|c|c|c|c|c|c|c|c|}
\hline & \multicolumn{4}{|c|}{ BNNTs nanofluid 0.001 wt.\% at } & \multicolumn{4}{c|}{ BNNTs nanofluid 0.001 wt.\% at } \\
$\mathbf{3 0}^{\mathbf{0}} \mathbf{C}$ & \multicolumn{4}{|c|}{$\mathbf{5 0}^{\mathbf{0}} \mathbf{C}$} \\
\hline No. & $\mathrm{R}_{\mathrm{th}}(\mathrm{W} / \mathrm{K})$ & $\Delta \mathrm{P}(\mathrm{psi})$ & $\begin{array}{c}\mathrm{R}_{\mathrm{th}} \mathrm{cf} . \\
(\%)\end{array}$ & $\begin{array}{c}\Delta \mathrm{P} \text { cf. } \\
(\%)\end{array}$ & $\mathrm{R}_{\mathrm{th}}(\mathrm{W} / \mathrm{K})$ & $\Delta \mathrm{P}(\mathrm{psi})$ & $\begin{array}{c}\mathrm{R}_{\mathrm{th}} \mathrm{cf} . \\
(\%)\end{array}$ & $\begin{array}{c}\Delta \mathrm{P} \text { cf. } \\
(\%)\end{array}$ \\
\hline 1 & 0.0890 & 19.2 & 5.21 & -48.7 & 0.0891 & 13.0 & 2.82 & -45.2 \\
\hline 2 & 0.0883 & 19.5 & 4.39 & -48.0 & 0.0880 & 14.2 & 1.45 & -40.1 \\
\hline 3 & 0.0857 & 21.3 & 1.26 & -43.1 & 0.0880 & 13.4 & 1.54 & -43.1 \\
\hline 4 & 0.0855 & 22.7 & 1.08 & -39.3 & 0.0861 & 15.0 & -0.66 & -36.6 \\
\hline 5 & 0.0836 & 23.2 & -1.15 & -38.0 & 0.0852 & 16.1 & -1.78 & -31.8 \\
\hline 6 & 0.0822 & 25.5 & -2.86 & -31.9 & 0.0846 & 17.0 & -2.45 & -28.0 \\
\hline
\end{tabular}

Although improvement of the thermal resistance is often followed up with the increase in the pressure drop, optimization has shown the possibility of further minimizing both the thermal resistance and pressure drop for best MCHS performance with BNNTs nanofluid 0.001 wt.\%. Two options are possible to decrease both the thermal resistance and pressure drop at $30^{\circ} \mathrm{C}$ and $50^{\circ} \mathrm{C}$. Referring to Table 10 , BNNTs nanofluid $0.001 \mathrm{wt} \%$ has improved its thermal resistance at $30^{\circ} \mathrm{C}$ and $50^{\circ} \mathrm{C}$ by $2.86 \%$ and $2.45 \%$, respectively with a reduction in the pressure drop of more than $28 \%$. For comparison purpose, Figure 5 is a bar chart of the least thermal resistance for all three fluids at $30^{\circ} \mathrm{C}$ and $50^{\circ}$. Table 11 includes the percentage difference of TX-100 mix and BNNTs nanofluid $0.001 \mathrm{wt} . \%$ with distilled water under optimized conditions of the aspect ratio and wall width to channel ratio. Again, equation (21) is used, where $z$ is the thermal resistance or pressure drop of TX-100 mix and BNNTs nanofluid $0.001 \mathrm{wt}$ \% with optimization and $y$ is the thermal resistance or pressure drop of distilled water with optimization.
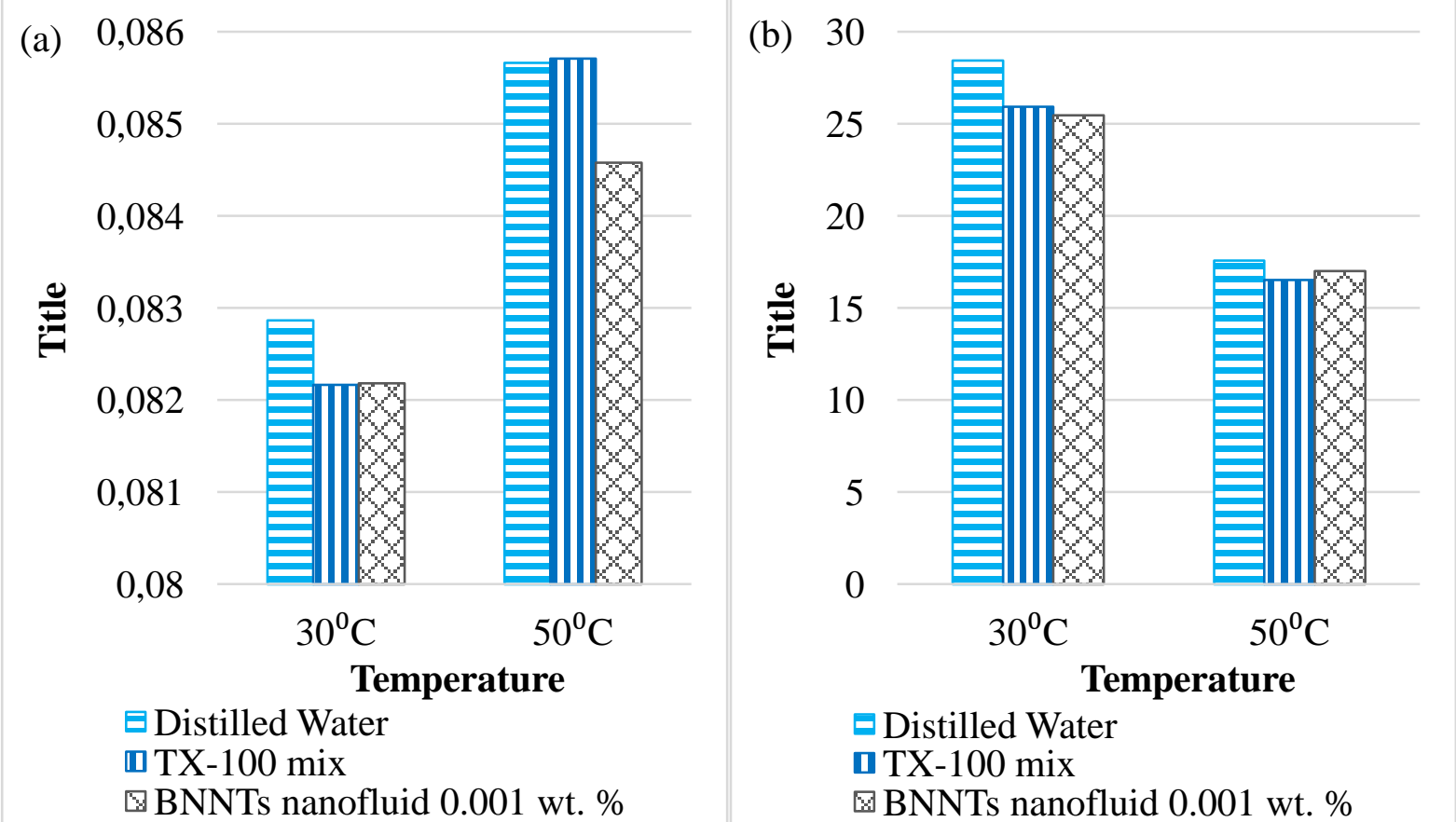

Figure 5: Minimum thermal resistance, $R_{t h}$, and associated pressure drop, $\Delta P$, at $30^{\circ} \mathrm{C}$ and $50^{\circ} \mathrm{C}$ 
Table 11: Comparison of minimum thermal resistance, $R_{t h}$, and associated pressure drop, $\Delta P$, for all fluids

\begin{tabular}{|l|c|c|c|c|c|c|}
\hline & \multicolumn{3}{|c|}{ Thermal Resistance, $\mathbf{R}_{\text {th }}(\mathbf{K} / \mathbf{W})$} & \multicolumn{3}{c|}{ Pressure Drop, $\Delta$ P (psi) } \\
\hline & $\begin{array}{c}\text { Distilled } \\
\text { Water } \\
\left(\mathrm{H}_{2} \mathrm{O}\right)\end{array}$ & $\begin{array}{c}\mathrm{TX}-100 \\
\text { mix }\end{array}$ & $\begin{array}{c}\text { BNNTs } \\
\text { nanofluid } \\
0.001 \\
\text { wt.\% }\end{array}$ & $\begin{array}{c}\text { Distilled } \\
\text { Water } \\
\left(\mathrm{H}_{2} \mathrm{O}\right)\end{array}$ & $\begin{array}{c}\text { TX-100 } \\
\text { mix }\end{array}$ & $\begin{array}{c}\text { BNNTs } \\
\text { nanofluid } \\
0.001 \\
\text { wt.\% }\end{array}$ \\
\hline $30^{0} \mathrm{C}$ & 0.0829 & 0.0822 & 0.0822 & 28.4 & 25.9 & 25.5 \\
\hline $50^{0} \mathrm{C}$ & 0.0857 & 0.0857 & 0.0846 & 17.6 & 16.5 & 17.0 \\
\hline $\begin{array}{l}30^{0} \mathrm{C}- \\
\text { percentage } \\
\text { difference } \\
\begin{array}{l}\text { compared to } \\
\text { H2O. }\end{array}\end{array}$ & - & $-0.8 \%$ & $-0.8 \%$ & - & $-8.8 \%$ & $-10.4 \%$ \\
\hline $\begin{array}{l}50^{0} \mathrm{C}- \\
\text { percentage } \\
\text { difference } \\
\begin{array}{l}\text { compared to } \\
\text { H2O. }\end{array}\end{array}$ & - & $0.05 \%$ & $-1.3 \%$ & - & $-6.1 \%$ & $-3.2 \%$ \\
\hline
\end{tabular}

At $30^{\circ} \mathrm{C}$, both Figure 5 and Table 11 evidence BNNTs nanofluid $0.001 \mathrm{wt} . \%$ does not reduce the thermal resistance as compared to TX-100 mix, both percentages being identical. Hydrodynamically, the pressure drop induced by BNNTs nanofluid $0.001 \mathrm{wt} \%$ might be mainly due to the presence of TX-100 mix as TX-100 reduces the pressure drop by $8.8 \%$. While BNNTs nanofluid $0.001 \mathrm{wt} \%$ further reduces the pressure drop by $1.6 \%$. At this temperature surfactant TX-100 might be the root of the improvement rather than the BNNTs even with optimization of microchannel design. This suggests that surfactant TX-100 could be the reason behind the drop in thermal resistance at $30^{\circ} \mathrm{C}$ and surfactant plays a significant role in low temperature MCHS application.

At $50^{\circ} \mathrm{C}$, BNNTs nanofluid $0.001 \mathrm{wt} \%$ performance optimization improves the thermal performance of the MCHS by $1.3 \%$ compared to distilled water. Although the TX100 mix has insignificant difference for its thermal resistance compared to water, optimization indicates a pressure drop reduction to 16.52 psi possibly due to the lower viscosity. Optimization has shown the potential of achieving simultaneous conflicting objectives, in the current study minimization of the thermal resistance and pressure drop. Particularly for BNNTs nanofluid $0.001 \mathrm{wt} . \%$, the reduction of thermal resistance was not accompanied with higher pressure drop.

With multiple solutions provided through optimization, Table 12 and 13 present the dimensions for channel and wall width including the number of microchannels, $n$, for balance performance and minimum thermal resistance, respectively. These dimensions are set as reference for the possible outcomes of selected desired objective(s), that of a balance between the thermal resistance and pressure drop, and that of minimum thermal resistance only, both tables have a fixed channel height of $302 \mu \mathrm{m}$. 
Table 12: Balanced performance for optimized MCHS for BNNTs nanofluid 0.001wt.\%

\begin{tabular}{|c|c|c|c|c|c|c|c|c|c|c|}
\hline & \multicolumn{5}{|c|}{$\begin{array}{l}\text { BNNTs nanofluid } 0.001 \text { wt. } \% \text { at } \\
\qquad 30^{\circ} \mathrm{C}\end{array}$} & \multicolumn{5}{|c|}{$\begin{array}{l}\text { BNNTs nanofluid } 0.001 \text { wt. } \% \text { at } \\
50^{\circ} \mathrm{C}\end{array}$} \\
\hline No. & $\begin{array}{c}\mathrm{R}_{\text {th }} \\
(\mathrm{W} / \mathrm{K})\end{array}$ & $\begin{array}{c}\Delta \mathrm{P} \\
(\mathrm{psi})\end{array}$ & $\begin{array}{c}\mathrm{w}_{\mathrm{c}} \\
(\mu \mathrm{m})\end{array}$ & $\begin{array}{c}\mathrm{W}_{\mathrm{w}} \\
(\mu \mathrm{m})\end{array}$ & $\mathrm{n}$ & $\mathrm{R}_{\mathrm{th}}(\mathrm{W} / \mathrm{K})$ & $\Delta \mathrm{P}(\mathrm{psi})$ & $\begin{array}{c}\mathrm{w}_{\mathrm{c}} \\
(\mu \mathrm{m})\end{array}$ & $\begin{array}{c}\mathrm{W}_{\mathrm{w}} \\
(\mu \mathrm{m})\end{array}$ & $\mathrm{n}$ \\
\hline 1 & 0.147 & 5.43 & 106.4 & 16.6 & 81 & 0.1 & 3.30 & 113.4 & 24.5 & 72 \\
\hline 2 & 0.144 & 6.26 & 106.4 & 31.6 & 72 & 0.132 & 4.39 & 91.4 & 14.7 & 94 \\
\hline 3 & 0.143 & 6.68 & 105.1 & 36.2 & 70 & 0.124 & 5.11 & 87.2 & 20.3 & 93 \\
\hline 4 & 0.132 & 6.78 & 95.4 & 18.9 & 87 & 0.122 & 5.58 & 77.4 & 9.4 & 115 \\
\hline 5 & 0.127 & 7.30 & 92.6 & 20.5 & 88 & 0.114 & 6.38 & 72.9 & 10.9 & 119 \\
\hline 6 & 0.126 & 7.66 & 85.8 & 11.9 & 102 & 0.106 & 8.15 & 72.6 & 29.1 & 98 \\
\hline 7 & 0.118 & 9.04 & 85.4 & 26.1 & 89 & 0.103 & 8.76 & 61.3 & 9.7 & 140 \\
\hline
\end{tabular}

Table 13: Minimum thermal resistance for an optimized MCHS for BNNTs nanofluid 0.001 wt. $\%$

\begin{tabular}{|c|c|c|c|c|c|c|c|c|c|c|}
\hline & \multicolumn{5}{|c|}{$\begin{array}{l}\text { BNNTs nanofluid } 0.001 \text { wt. \% at } \\
30^{\circ} \mathrm{C}\end{array}$} & \multicolumn{5}{|c|}{$\begin{array}{c}\text { BNNTs nanofluid } 0.001 \text { wt. \% at } \\
50^{\circ} \mathrm{C}\end{array}$} \\
\hline No. & $\begin{array}{c}\mathrm{R}_{\mathrm{th}} \\
(\mathrm{W} / \mathrm{K})\end{array}$ & $\begin{array}{c}\Delta \mathrm{P} \\
(\mathrm{psi})\end{array}$ & $\begin{array}{c}\mathrm{W}_{\mathrm{c}} \\
(\mu \mathrm{m})\end{array}$ & $\begin{array}{c}\mathrm{W}_{\mathrm{w}} \\
(\mu \mathrm{m})\end{array}$ & $\mathrm{n}$ & $\mathrm{R}_{\mathrm{th}}(\mathrm{W} / \mathrm{K})$ & $\Delta \mathrm{P}(\mathrm{psi})$ & $\begin{array}{c}\mathrm{w}_{\mathrm{c}} \\
(\mu \mathrm{m})\end{array}$ & $\begin{array}{c}\mathrm{W}_{\mathrm{w}} \\
(\mu \mathrm{m})\end{array}$ & $\mathrm{n}$ \\
\hline 1 & 0.0890 & & 57.6 & & 126 & 891 & 0 & 54.4 & 18.9 & 136 \\
\hline 2 & 0.0883 & 19.5 & 56.7 & 20.0 & 130 & 0.0880 & 14.2 & 53.9 & 23.7 & 128 \\
\hline 3 & 0.0857 & 21.3 & 54.1 & 24.3 & 127 & 0.0880 & 13.4 & 52.2 & 15.9 & 146 \\
\hline 4 & 0.0855 & 22.7 & 52.1 & 14.5 & 150 & 0.0861 & 15.0 & 51.6 & 21.1 & 137 \\
\hline 5 & 0.0836 & 23.2 & 50.5 & 15.7 & 150 & 0.0852 & 16.1 & 50.8 & 23.9 & 133 \\
\hline 6 & 0.0822 & 25.5 & 50.1 & 20.7 & 141 & 0.0846 & 17.0 & 50.3 & 25.9 & 131 \\
\hline
\end{tabular}

Referring to both Table 12 and Table 13, the minimum size of a channel width is 50.1 $\mu \mathrm{m}$ which is certainly able to be fabricated even with the same process of $\mathrm{KOH}$ etching as the pioneer MCHS by Tuckerman and Pease (1981). The combinations of various channel widths and wall widths show a significant difference in channel numbers, $n$ per $1 \mathrm{~cm}^{2}$ of a MCHS, to improve convective thermal resistance as in equation (5). Referring to Table 12, the two obtained solutions lead to a minimum dimension of wall width of about $10 \mu \mathrm{m}$. According to Lindroos et al. (2010), wall dimensions above $5 \mu \mathrm{m}$ can be produced with Deep-Reactive Ion Etching (DRIE) method smoothly without any defect of scalloping or wavy wall, which all optimized solutions given in Table 12 and 13 are possible to be manufactured steadily. Wavy or scalloping will cause a higher pressure drop as the surface area of microchannel increases which current model for pressure drop used will be irrelevant. Lindroos et al. (2010) explained that DRIE method is a preferable fabrication process for a MCHS compared to $\mathrm{KOH}$ etching in term of cost, speed, and depth but limited to etch on one side of a substrate only. Recently, the method has been used by Back et al. (2019) producing channel and wall width of $19 \mu \mathrm{m}$ and $11 \mu \mathrm{m}$ respectively for their $5 \mathrm{~mm}$ x $5 \mathrm{~mm}$ MCHS experimentation 
including its manifold to direct coolants into the MCHS and expel the hot coolant. This confirms that all of the optimized options might be able to be produced without any complication. It could be a design reference to produce the best performance of a MCHS utilizing BNNTs nanofluids 0.001 wt.\%. 


\section{Conclusion}

Accuracy and reliability of the MCHS optimization output is directly driven by the thermophysical properties of the fluids, in particular newly developed potential coolants such as nanofluids. Therefore, it is desirable to model expected performances based on real data extracted through experiments. This was done in the present work considering Boron Nitride Nanotubes (BNNTs) nanofluid with nanotube content of $0.001 \mathrm{wt} . \%$, its base fluid, a mixture of distilled water and Triton X-100 as surfactant, and distilled water as a reference, to distinguish the impact of surfactant and nanotubes in MCHS performance. The thermal and hydrodynamic performances of MCHS with these fluids were evaluated from MOPSO optimization technique and at two distinct relevant temperatures, 30 and $50^{\circ} \mathrm{C}$ respectively. The main findings of this study are the following:

1) Adding $0.001 \mathrm{wt} . \%$ of BNNTs in base fluid at $30^{\circ} \mathrm{C}$ has no significant impact on MCHS performance as surfactant TX-100 in distilled water already decreases thermal resistance with consequence of pressure drop increase. Optimizing MCHS at $30^{\circ} \mathrm{C}$ further reduces pressure drop as low as $8.8 \%$, highlighting that TX-100 mix is able to improve MCHS performance without the need of nanotubes. The surfactant significantly impacts MCHS performance for low temperature MCHS system.

2) At $50^{\circ} \mathrm{C}$, surfactant $\mathrm{TX}-100$ in distilled water paired cooperatively with $0.001 \mathrm{wt} \%$ BNNTs as the base fluid has no deterioration of thermal resistance and reduces pressure drop of MCHS by 3.96\%. This mitigates BNNTs nanofluid $0.001 \mathrm{wt} \%$ increase of pressure drop around $2 \%$ and improves the thermal resistance of MCHS system by $1.25 \%$. Optimizing MCHS at $50^{\circ} \mathrm{C}$ with TX-100 mix and BNNTs nanofluid $0.001 \mathrm{wt} . \%$, the nanofluid acquired lower pressure drop by $3.2 \%$ due to the surfactant with a little improvement in thermal resistance. BNNTs shows a good relationship with surfactant TX-100 in distilled water for higher temperature of MCHS application and performance, due to the increase of thermal properties of nanofluid, without significant change in viscosity.

3) The heuristic approach of MOPSO has shown various options opened to designers and engineers; a balanced thermal and hydrodynamic performance, or any of the combinations of the optimal solutions generated. The options selected will depend on end-use, all optimized solutions are possible to be manufactured with lowest wall width dimension for about $10 \mu \mathrm{m}$ and up to 150 microchannels.

As a continuation, higher concentrations of BNNTs in nanofluid could be investigated to explore more Pareto front patterns for optimal results with lower thermal resistance and pressure drop, within a trade-off between thermal properties and viscosity of nanofluids. A similar modelling and optimization approach could also be performed with other types of nanofluids, and higher temperature range.

\section{Acknowledgements}


The authors acknowledge the funding from the Research University Grant Universiti Teknologi Malaysia, GUP Vot 19H60, to complete this research. We also acknowledge Ministerio de Ciencia, Innovación y Universidades del Gobierno de España for funding under Grant No. RTI2018-096393-B-I00, and support provided by the Malaysian French Embassy for this collaborative research.

\section{Nomenclature}

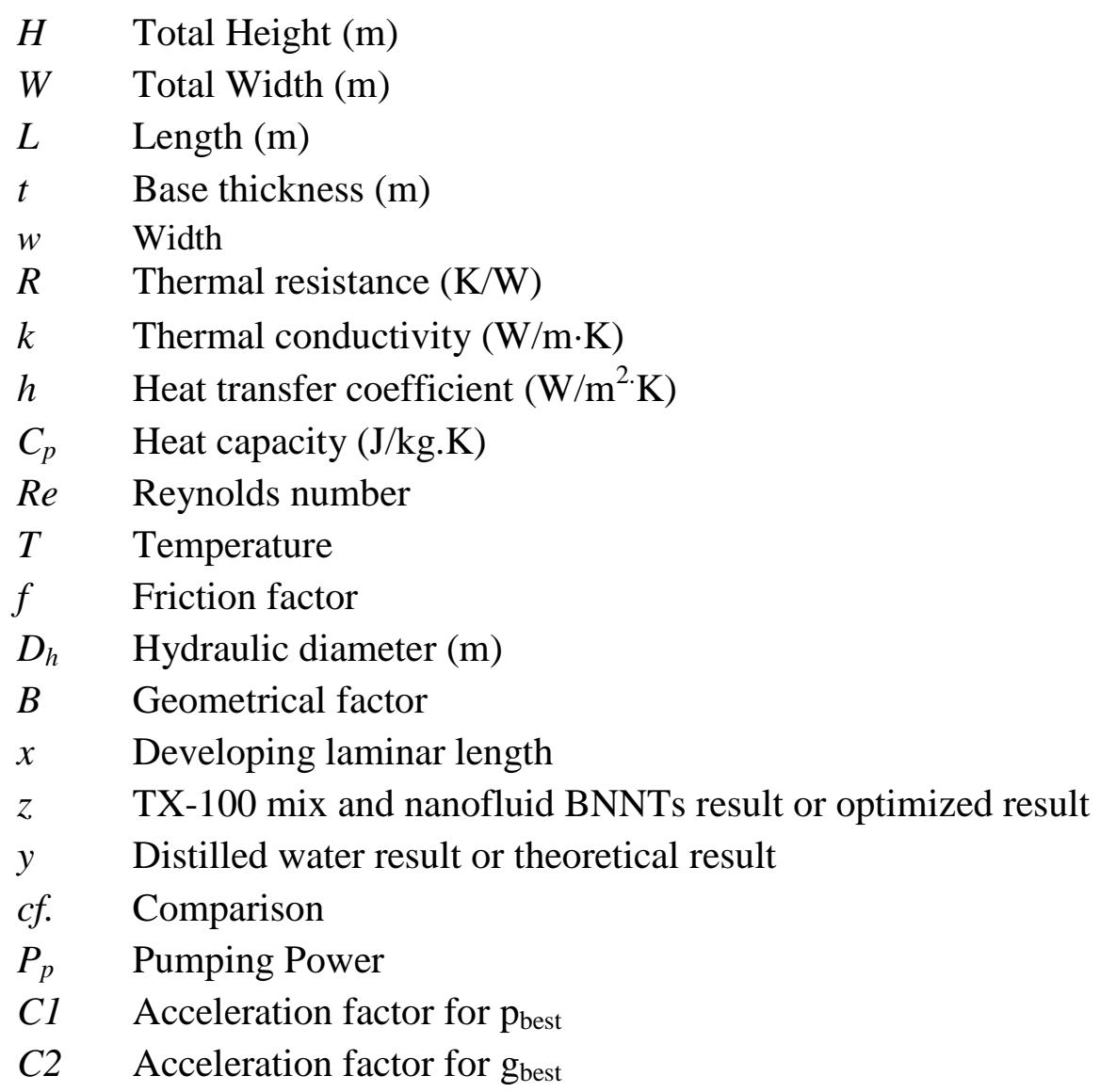

\section{Greek symbols}

$\begin{array}{ll}\alpha & \text { Channel aspect ratio } \\ \beta & \text { Wall width ratio } \\ \eta & \text { Fin efficiency } \\ \mu & \text { Dynamic viscosity }(\mathrm{kg} / \mathrm{s} \cdot \mathrm{m}) \\ \Delta P & \text { Pressure drop }(\mathrm{Pa}) \\ \rho & \text { Density }\left(\mathrm{kg} / \mathrm{m}^{3}\right) \\ v & \text { Average velocity }(\mathrm{m} / \mathrm{s})\end{array}$

$\begin{array}{ll}\text { Subscript } & \\ c & \text { Channel } \\ w & \text { Wall } \\ a v & \text { Average } \\ h s & \text { Heat sink }\end{array}$




$\begin{array}{ll}f & \text { Fluid } \\ \text { th } & \text { Thermal } \\ \text { app } & \text { Apparent } \\ \text { cond } & \text { Conductive } \\ \text { conv } & \text { Convective } \\ \text { cap } & \text { Capacitive } \\ b & \text { Base/substrate }\end{array}$




\section{References}

Adham, A. M., Mohd-Ghazali, N., \& Ahmad, R. (2012). Optimization of an ammoniacooled rectangular microchannel heat sink using multi-objective non-dominated sorting genetic algorithm (NSGA2). Heat and Mass Transfer, 48(10), 1723-1733. https://doi.org/10.1007/s00231-012-1016-8

Adham, A. M., Mohd-Ghazali, N., \& Ahmad, R. (2016). Optimization of nanofluid-cooled microchannel heat sink. Thermal Science, 20(1), 109-118. https://doi.org/10.2298/TSCI130517163A

Ahmed, H. E., Ahmed, M. I., Seder, I. M. F., \& Salman, B. H. (2016). Experimental investigation for sequential triangular double-layered microchannel heat sink with nanofluids. International Communications in Heat and Mass Transfer, 77, 104-115. https://doi.org/10.1016/j.icheatmasstransfer.2016.06.010

Alfellag, M. A., Ahmed, H. E., Fadhil, O. T., \& Sh. Kherbeet, A. (2019). Optimal hydrothermal design of microchannel heat sink using trapezoidal cavities and solid/slotted oval pins. Applied Thermal Engineering, 158, 113765. https://doi.org/https://doi.org/10.1016/j.applthermaleng.2019.113765

Anbumeenakshi, C., \& Thansekhar, M. R. (2017). On the effectiveness of a nanofluid cooled microchannel heat sink under non-uniform heating condition. Applied Thermal Engineering, 113, 1437-1443. https://doi.org/10.1016/j.applthermaleng.2016.11.144

Arani, A. A. A., Akbari, O. A., Safaei, M. R., Marzban, A., Alrashed, A. A. A. A., Ahmadi, G. R., \& Nguyen, T. K. (2017). Heat transfer improvement of water/single-wall carbon nanotubes (SWCNT) nanofluid in a novel design of a truncated double-layered microchannel heat sink. International Journal of Heat and Mass Transfer, 113, 780-795. https://doi.org/10.1016/j.ijheatmasstransfer.2017.05.089

Askar, A. H., Kadhim, S. A., \& Mshehid, S. H. (2020). The surfactants effect on the heat transfer enhancement and stability of nanofluid at constant wall temperature. Heliyon, 6(7), e04419. https://doi.org/https://doi.org/10.1016/j.heliyon.2020.e04419

Azizi, Z., Alamdari, A., \& Malayeri, M. R. (2016). Thermal performance and friction factor of a cylindrical microchannel heat sink cooled by $\mathrm{Cu}$-water nanofluid. In Applied Thermal Engineering, 99, 970-978. https://doi.org/10.1016/j.applthermaleng.2016.01.140

Back, D., Drummond, K. P., Sinanis, M. D., Weibel, J. A., Garimella, S. V., Peroulis, D., \& Janes, D. B. (2019). Design, Fabrication, and Characterization of a Compact Hierarchical Manifold Microchannel Heat Sink Array for Two-Phase Cooling. IEEE Transactions on Components, Packaging and Manufacturing Technology, 9(7), 1291-1300. https://doi.org/10.1109/TCPMT.2019.2899648

Bahiraei M., Jamshidmofid M., Goodarzi M. (2019) Efficacy of a hybrid nanofluid in a new microchannel heat sink equipped with both secondary channels and ribs, Journal of Molecular Liquids, 273, 88-98, https://doi.org/10.1016/j.molliq.2018.10.003.

Bannatyne, R. (2016). ARM Cortex-MO stretches the limits of high temperature operation. Community.Arm. $\quad$ https://community.arm.com/developer/ipproducts/processors/b/processors-ip-blog/posts/arm-cortex-m0-stretches-the-limits-of- 
high-temperature-operation

Bejan, A. (1995). Convection Heat Transfer (2nd ed.). Wiley.

Chai, L., Xia, G., Wang, L., Zhou, M., \& Cui, Z. (2013). Heat transfer enhancement in microchannel heat sinks with periodic expansion-constriction cross-sections. International Journal of Heat and Mass Transfer, 62(1), 741-751. https://doi.org/10.1016/j.ijheatmasstransfer.2013.03.045

Chan, I. S., Ghazali, N. M., Zolpakar, N. A., \& Mohamad, M. (2020). Four-Variable Simultaneous Optimization of the Cooling and Acoustic Power with Particle Swarm Optimization. International Journal of Air-Conditioning and Refrigeration, 28(02). https://doi.org/10.1142/S2010132520500121

Chan, Y. C., Lee, Y. K., \& Zohar, Y. (2006). High-throughput design and fabrication of an integrated microsystem with high aspect-ratio sub-micron pillar arrays for free-solution micro capillary electrophoresis. Journal of Micromechanics and Microengineering, 16(4), 699-707. https://doi.org/10.1088/0960-1317/16/4/005

Chen, B., Miao, J., \& Tay, F. E. H. (2007). Fabrication and characterization of DRIEmicromachined electrostatic microactuators for hard disk drives. Microsystem Technologies, 13(1), 11-19. https://doi.org/10.1007/s00542-006-0246-4

Choi, T. J., Jang, S. P., \& Kedzierski, M. A. (2018). Effect of surfactants on the stability and solar thermal absorption characteristics of water-based nanofluids with multi-walled carbon nanotubes. International Journal of Heat and Mass Transfer, 122, 483-490. https://doi.org/10.1016/j.ijheatmasstransfer.2018.01.141

Chou, D. (2015). Infrastructure. In Practical Guide to Clinical Computing Systems (2nd ed.). Elsevier Inc. https://doi.org/10.1016/B978-0-12-420217-7.00004-3

Clerc, M. (1999). The swarm and the queen: towards a deterministic and adaptive particle swarm optimization. Proceedings of the 1999 Congress on Evolutionary ComputationCEC99 (Cat. No. 99TH8406), 3, 1951-1957. https://doi.org/10.1109/CEC.1999.785513

Copeland, D. (2000). Optimization of parallel plate heatsinks for forced convection. Annual IEEE Semiconductor Thermal Measurement and Management Symposium, 266-272. https://doi.org/10.1109/stherm.2000.837093

Dokken, C. B., \& Fronk, B. M. (2018). Optimization of 3D printed liquid cooled heat sink designs using a micro-genetic algorithm with bit array representation. Applied Thermal Engineering, 143, 316-325. https://doi.org/10.1016/j.applthermaleng.2018.07.113

Duangthongsuk, W., \& Wongwises, S. (2017). An experimental investigation on the heat transfer and pressure drop characteristics of nanofluid flowing in microchannel heat sink with multiple zigzag flow channel structures. Experimental Thermal and Fluid Science, 87, 30-39. https://doi.org/10.1016/j.expthermflusci.2017.04.013

Eberhart, R., \& Kennedy, J. (1995). A new optimizer using particle swarm theory. MHS'95. Proceedings of the Sixth International Symposium on Micro Machine and Human Science, 39-43. https://doi.org/10.1109/MHS.1995.494215

Eberhart, \& Shi, Y. (2001). Particle swarm optimization: developments, applications and resources. Proceedings of the 2001 Congress on Evolutionary Computation (IEEE Cat. No.01TH8546), 1, 81-86. https://doi.org/10.1109/CEC.2001.934374 
Estellé, P., Halelfadl, S., \& Maré, T. (2015). Thermal conductivity of CNT water based nanofluids: Experimental trends and models overview. Journal of Thermal Engineering, 1(2), 381-390. https://doi.org/10.18186/jte.92293

Garg, H., Negi, V. S., Garg, N., \& Lall, A. (2015). Numerical and experimental analysis of microchannel heat transfer for nanoliquid coolant using different shapes and geometries. Proceedings of the Institution of Mechanical Engineers, Part C: Journal of Mechanical Engineering Science, 229(11), 2056-2065. https://doi.org/10.1177/0954406214550846

Ge, Y., Wang, S., Liu, Z., \& Liu, W. (2019). Optimal shape design of a minichannel heat sink applying multi-objective optimization algorithm and three-dimensional numerical method. Applied Thermal Engineering, 148, 120-128. https://doi.org/10.1016/j.applthermaleng.2018.11.038

Ghasemi, S. E., Ranjbar, A. A., \& Hosseini, M. J. (2017). Numerical study on effect of CuOwater nanofluid on cooling performance of two different cross-sectional heat sinks. Advanced Powder Technology, 28(6), 1495-1504. https://doi.org/10.1016/j.apt.2017.03.019

Glassbrenner, C. J., \& Slack, G. A. (1964). Thermal Conductivity of Silicon and Germanium from $3^{\circ} \mathrm{K}$ to the Melting Point. Physical Review, 134(4A), A1058-A1069. https://doi.org/10.1103/PhysRev.134.A1058

Gómez-Villarejo, R., Aguilar, T., Hamze, S., Estellé, P., \& Navas, J. (2019). Experimental analysis of water-based nanofluids using boron nitride nanotubes with improved thermal properties. Journal of Molecular Liquids, 277, 93-103. https://doi.org/https://doi.org/10.1016/j.molliq.2018.12.093

Hajmohammadi, M. R., \& Toghraei, I. (2018). Optimal design and thermal performance improvement of a double-layered microchannel heat sink by introducing Al2O3 nanoparticles into the water. Physica A: Statistical Mechanics and Its Applications, 505, 328344. https://doi.org/10.1016/j.physa.2018.03.040

Halelfadl, S., Adham, A. M., Mohd-Ghazali, N., Maré, T., Estellé, P., \& Ahmad, R. (2014). Optimization of thermal performances and pressure drop of rectangular microchannel heat sink using aqueous carbon nanotubes based nanofluid. Applied Thermal Engineering, 62(2), 492-499. https://doi.org/10.1016/j.applthermaleng.2013.08.005

Halelfadl, S., Maré, T., \& Estellé, P. (2014). Efficiency of carbon nanotubes water based nanofluids as coolants. Experimental Thermal and Fluid Science, 53, 104-110. https://doi.org/10.1016/j.expthermflusci.2013.11.010

Hasan, M. I. (2014). Investigation of flow and heat transfer characteristics in micro pin fin heat sink with nanofluid. Applied Thermal Engineering, 63(2), 598-607. https://doi.org/https://doi.org/10.1016/j.applthermaleng.2013.11.059

Hassan, R., Cohanim, B., de Weck, O., \& Venter, G. (2005). A Comparison of Particle Swarm Optimization and the Genetic Algorithm. In 46th AIAA/ASME/ASCE/AHS/ASC Structures, Structural Dynamics and Materials Conference. American Institute of Aeronautics and Astronautics. https://doi.org/doi:10.2514/6.2005-1897

Hemmat Esfe, M., Hajmohammad, H., Moradi, R., \& Abbasian Arani, A. A. (2017). Multiobjective optimization of cost and thermal performance of double walled carbon nanotubes/water nanofluids by NSGA-II using response surface method. Applied 
Thermal

Engineering,

https://doi.org/10.1016/j.applthermaleng.2016.10.129

Ijam, A., \& Saidur, R. (2012). Nanofluid as a coolant for electronic devices (cooling of electronic devices). Applied Thermal Engineering, 32(1), 76-82. https://doi.org/10.1016/j.applthermaleng.2011.08.032

Intel Corporation. (2020, January 29). Thermal Management for Intel $₫$ Xeon ${ }^{\circledR}$ Processors. http://www.intel.com/content/www/us/en/support/articles/000006710/processors/intelxeon-processors.html

Jalali, E., Ali Akbari, O., Sarafraz, M.M., Abbas, T., Safaei, M.R. (2019) Heat transfer of Oil/MWCNT nanofluid jet injection inside a rectangular microchannel. Symmetry , 11, 757. https://doi.org/10.3390/sym 11060757

Jiang, X., Zhang, S., Li, Y., \& Pan, C. (2020). High performance heat sink with counter flow diverging microchannels. International Journal of Heat and Mass Transfer, 162, 120344. https://doi.org/https://doi.org/10.1016/j.ijheatmasstransfer.2020.120344

Kamali, R., Jalali, Y., \& Binesh, A. R. (2013). Investigation of multiwall carbon nanotubebased nanofluid advantages in microchannel heat sinks. Micro and Nano Letters, 8(6), 319-323. https://doi.org/10.1049/mnl.2012.0803

Kiihamäki, J., \& Franssila, S. (1999). Pattern shape effects and artefacts in deep silicon etching. Journal of Vacuum Science \& Technology A: Vacuum, Surfaces, and Films, 17(4), 2280-2285. https://doi.org/10.1116/1.581761

Kim, S. J., \& Kim, D. (1999). Forced Convection in Microstructures for Electronic Equipment Cooling. Journal of Heat Transfer, 121(3), 639-645.

Kim, S., Tserengombo, B., Choi, S. H., Noh, J., Huh, S., Choi, B., Chung, H., Kim, J., \& Jeong, H. (2018). Experimental investigation of dispersion characteristics and thermal conductivity of various surfactants on carbon based nanomaterial. International Communications in Heat and Mass Transfer, 91, 95-102. https://doi.org/10.1016/j.icheatmasstransfer.2017.12.011

Kleiner, M. B., Kuhn, S. A., \& Haberger, K. (1995). High performance forced air cooling scheme employing microchannel heat exchangers. IEEE Transactions on Components, Packaging, and Manufacturing Technology: Part A, 18(4), 795-804. https://doi.org/10.1109/95.477466

Knight, R. W., Goodling, J. S., \& Gross, B. E. (1992). Optimal thermal design of air cooled forced convection finned heat sinks-experimental verification. IEEE Transactions on Components, Hybrids, and Manufacturing Technology, 15(5), 754-760 http://doi.org/10.1109/33.180040.

Leong, K. Y., Mohd Hanafi, N., Mohd Sohaimi, R., \& Amer, N. H. (2016). The effect of surfactant on stability and thermal conductivity of carbon nanotube based nanofluids. Thermal Science, 20(2), 429-436. https://doi.org/10.2298/TSCI130914078L

Lin Y., Luo Y., Li W., Cao Y., Tao Z., Shih T. I-P. (2021) Single-phase and Two-phase Flow and Heat Transfer in Microchannel Heat Sink with Various Manifold Arrangements, International Journal of Heat and Mass Transfer, 171, 121118, https://doi.org/10.1016/j.ijheatmasstransfer.2021.121118. 
Lindroos, V., Tilli, M., Lehto, A., \& Motooka, T. (2010). Handbook of Silicon Based MEMS Materials and Technologies. https://doi.org/10.1016/C2009-0-19030-X

Lips, B., \& Puers, R. (2016). Three step deep reactive ion etch for high density trench etching. Journal of Physics: Conference Series, 757(1). https://doi.org/10.1088/1742$6596 / 757 / 1 / 012005$

Ma, D. D., Xia, G. D., Jia, Y. T., Li, Y. F., \& Wang, J. (2017). Multi-parameter optimization for micro-channel heat sink under different constraint conditions. Applied Thermal Engineering, 120, 247-256. https://doi.org/10.1016/j.applthermaleng.2017.03.123

Ma, M., Zhai, Y., Yao, P., Li, Y., \& Wang, H. (2021). Effect of surfactant on the rheological behavior and thermophysical properties of hybrid nanofluids. Powder Technology, 379, 373-383. https://doi.org/https://doi.org/10.1016/j.powtec.2020.10.089

Mohammad, M. (2011). Intelligence modelling and active vibration control of flexible structures. (Doctoral Thesis, University of Sheffield, England, United Kingdom). Retrieved from https://ethos.bl.uk/OrderDetails.do?uin=uk.bl.ethos.554910

Mohammed, H. A., Bhaskaran, G., Shuaib, N. H., \& Abu-Mulaweh, H. I. (2011). Influence of nanofluids on parallel flow square microchannel heat exchanger performance. International Communications in Heat and Mass Transfer, 38(1), 1-9. https://doi.org/10.1016/j.icheatmasstransfer.2010.09.007

Mohammed, H. A., Gunnasegaran, P., \& Shuaib, N. H. (2010). Heat transfer in rectangular microchannels heat sink using nanofluids. International Communications in Heat and Mass Transfer, 37(10), 1496-1503. https://doi.org/10.1016/j.icheatmasstransfer.2010.08.020

Mohd-Ghazali, N., Estellé, P., Halelfadl, S., Maré, T., Siong, T. C., \& Abidin, U. (2019). Thermal and hydrodynamic performance of a microchannel heat sink with carbon nanotube nanofluids. Journal of Thermal Analysis and Calorimetry. https://doi.org/10.1007/s10973-019-08260-2

Pan, Y.-H., Zhao, R., Fan, X.-H., Nian, Y.-L., \& Cheng, W.-L. (2020). Study on the effect of varying channel aspect ratio on heat transfer performance of manifold microchannel heat sink. International Journal of Heat and Mass Transfer, 163, 120461. https://doi.org/https://doi.org/10.1016/j.ijheatmasstransfer.2020.120461

Peyghambarzadeh, S. M., Hashemabadi, S. H., Chabi, A. R., \& Salimi, M. (2014). Performance of water based $\mathrm{CuO}$ and $\mathrm{Al} 2 \mathrm{O} 3$ nanofluids in a $\mathrm{Cu}-\mathrm{Be}$ alloy heat sink with rectangular microchannels. Energy Conversion and Management, 86, 28-38. https://doi.org/https://doi.org/10.1016/j.enconman.2014.05.013

Pourfattah, F., Abbasian Arani A.A., Babaie M.R., Nguyen H.M., Asadi A. (2019) On the thermal characteristics of a manifold microchannel heat sink subjected to nanofluid using two-phase flow simulation. International Journal of Heat and Mass Transfer, 143, 118518, https://doi.org/10.1016/j.ijheatmasstransfer.2019.118518.

Prakash, C. (1978). Thermal conductivity variation of silicon with temperature. Microelectronics Reliability, 18(4), 333. https://doi.org/https://doi.org/10.1016/00262714(78)90573-5

Sakanova, A., Keian, C. C., \& Zhao, J. (2015). Performance improvements of microchannel heat sink using wavy channel and nanofluids. International Journal of Heat and Mass 
Transfer, 89, 59-74. https://doi.org/10.1016/j.ijheatmasstransfer.2015.05.033

Sarafraz, M. M., Nikkhah, V., Nakhjavani, M., \& Arya, A. (2017). Fouling formation and thermal performance of aqueous carbon nanotube nanofluid in a heat sink with rectangular parallel microchannel. Applied Thermal Engineering, 123, 29-39. https://doi.org/10.1016/j.applthermaleng.2017.05.056

Sarafraz, M. M., Nikkhah, V., Nakhjavani, M., \& Arya, A. (2018). Thermal performance of a heat sink microchannel working with biologically produced silver-water nanofluid: Experimental assessment. Experimental Thermal and Fluid Science, 91(April 2017), 509-519. https://doi.org/10.1016/j.expthermflusci.2017.11.007

Sarlak, A., Ahmadpour, A., \& Hajmohammadi, M. R. (2019). Thermal design improvement of a double-layered microchannel heat sink by using multi-walled carbon nanotube (MWCNT) nanofluids with non-Newtonian viscosity. Applied Thermal Engineering, 147(August 2018), 205-215. https://doi.org/10.1016/j.applthermaleng.2018.10.084

Shen, H., Zhang, Y., Wang, C. C., \& Xie, G. (2018). Comparative study for convective heat transfer of counter-flow wavy double-layer microchannel heat sinks in staggered arrangement. Applied Thermal Engineering, 137(March), 228-237. https://doi.org/10.1016/j.applthermaleng.2018.03.089

Shi, X., Li, S., Wei, Y., \& Gao, J. (2018). Numerical investigation of laminar convective heat transfer and pressure drop of water-based $\mathrm{Al} 2 \mathrm{O} 3$ nanofluids in a microchannel. International Communications in Heat and Mass Transfer, 90, 111-120. https://doi.org/10.1016/j.icheatmasstransfer.2017.11.007

Soleymani, Z., Rahimi, M., Gorzin, M., \& Pahamli, Y. (2020). Performance analysis of hotspot using geometrical and operational parameters of a microchannel pin-fin hybrid heat sink. International Journal of Heat and Mass Transfer, 159, 120141. https://doi.org/https://doi.org/10.1016/j.ijheatmasstransfer.2020.120141

Reddy, P. S., \& Chamkha, A. J. (2016). Influence of size, shape, type of nanoparticles, type and temperature of the base fluid on natural convection MHD of nanofluids. Alexandria Engineering Journal, 55(1), 331-341. https://doi.org/https://doi.org/10.1016/j.aej.2016.01.027

Tang, Y., Sandoughsaz, A., Owen, K. J., \& Najafi, K. (2018). Ultra Deep Reactive Ion Etching of High Aspect-Ratio and Thick Silicon Using a Ramped-Parameter Process. Journal of Microelectromechanical Systems, 27(4), 686-697. https://doi.org/10.1109/JMEMS.2018.2843722

Tuckerman, D. B., \& Pease, R. F. W. (1981). High-Performance Heat Sinking for VLSI. IEEE Electron Device Letters, EDL-2(5), 126-129. https://doi.org/10.1109/EDL.1981.25367

VORAGO Technologies Inc. (n.d). VA10800 - Extreme Temperature ARM® Cortex®-MO $\begin{array}{lllll}M C U & \text { Retrieved } & \text { December } & \text { 2020, from }\end{array}$ https://www.voragotech.com/products/va10800

Wang, T., Wu, H., Meng, J., \& Yan, W. (2020). Optimization of a double-layered microchannel heat sink with semi-porous-ribs by multi-objective genetic algorithm. International Journal of Heat and Mass Transfer, 149. https://doi.org/10.1016/j.ijheatmasstransfer.2019.119217. 
Wang, X. D., An, B., Lin, L., \& Lee, D. J. (2013). Inverse geometric optimization for geometry of nanofluid-cooled microchannel heat sink. Applied Thermal Engineering, 55(1-2), 87-94. https://doi.org/10.1016/j.applthermaleng.2013.03.010

Wong, K. C., \& Ang, M. L. (2017). Thermal hydraulic performance of a double-layer microchannel heat sink with channel contraction. International Communications in Heat and Mass Transfer, 81, 269-275. https://doi.org/10.1016/j.icheatmasstransfer.2016.09.013

Wu, R., Zhang, X., Fan, Y., Hu, R., \& Luo, X. (2019). A Bi-Layer compact thermal model for uniform chip temperature control with non-uniform heat sources by genetic-algorithm optimized microchannel cooling. International Journal of Thermal Sciences, 136, 337346. https://doi.org/10.1016/j.ijthermalsci.2018.10.047

Wusiman, K., Jeong, H., Tulugan, K., Afrianto, H., \& Chung, H. (2013). Thermal performance of multi-walled carbon nanotubes (MWCNTs) in aqueous suspensions with surfactants SDBS and SDS. International Communications in Heat and Mass Transfer, 41, 28-33. https://doi.org/10.1016/j.icheatmasstransfer.2012.12.002

Xia, G. D., Liu, R., Wang, J., \& Du, M. (2016). The characteristics of convective heat transfer in microchannel heat sinks using $\mathrm{Al} 2 \mathrm{O} 3$ and $\mathrm{TiO} 2$ nanofluids. International Communications in Heat and Mass Transfer, 76, 256-264. https://doi.org/10.1016/j.icheatmasstransfer.2016.05.034

Yang, M., Li, M.-T., Hua, Y.-C., Wang, W., \& Cao, B.-Y. (2020). Experimental study on single-phase hybrid microchannel cooling using HFE-7100 for liquid-cooled chips. International Journal of Heat and Mass Transfer, 160, 120230. https://doi.org/https://doi.org/10.1016/j.ijheatmasstransfer.2020.120230

Yang, Q., Zhao, J., Huang, Y., Zhu, X., Fu, W., Li, C., \& Miao, J. (2019). A diamond made microchannel heat sink for high-density heat flux dissipation. Applied Thermal Engineering, 158 ,

113804. https://doi.org/https://doi.org/10.1016/j.applthermaleng.2019.113804

Yu, J., Kang, S. W., Jeong, R. G., \& Banerjee, D. (2016). Experimental validation of numerical predictions for forced convective heat transfer of nanofluids in a microchannel. International Journal of Heat and Fluid Flow, 62, 203-212. https://doi.org/10.1016/j.ijheatfluidflow.2016.11.001

Zeng, S., Sun, Q., \& Lee, P. S. (2020). Thermohydraulic analysis of a new fin pattern derived from topology optimized heat sink structures. International Journal of Heat and Mass Transfer, 147 ,

118909. https://doi.org/https://doi.org/10.1016/j.ijheatmasstransfer.2019.118909

Zhai, Y., Li, Z., Wang, H., \& Xu, J. (2016). Analysis of field synergy principle and the relationship between secondary flow and heat transfer in double-layered microchannels with cavities and ribs. International Journal of Heat and Mass Transfer, 101, 190-197. https://doi.org/10.1016/j.ijheatmasstransfer.2016.05.025

Zhai, Y., Xia, G., Li, Z., \& Wang, H. (2016). A novel flow arrangement of staggered flow in double-layered microchannel heat sinks for microelectronic cooling. International Communications in Heat and Mass Transfer, 79, 98-104. https://doi.org/10.1016/j.icheatmasstransfer.2016.10.008 
